\title{
Article \\ Seasonality in Tourism: Do Senior Programs Mitigate It?
}

\author{
Paz Rico ${ }^{1}$, Bernardí Cabrer-Borrás ${ }^{1}$ and Francisco Morillas-Jurado ${ }^{2, * \mathbb{D}}$ \\ 1 Departament d'Análisis Econòmica, Facultat d'Economia, Campus dels Tarongers s/n, \\ Universitat de València Estudi General, 46022 Valencia, Spain; paz.rico@uv.es (P.R.); Cabrer@uv.es (B.C.-B.) \\ 2 Departament d'Economia Aplicada, Facultat d'Economia, Campus dels Tarongers s/n, \\ Universitat de València Estudi General, 46022 Valencia, Spain \\ * Correspondence: Francisco.Morillas@uv.es; Tel.: +34-961-625-384
}

Citation: Rico, P.; Cabrer-Borrás, B.; Morillas-Jurado, F. Seasonality in Tourism: Do Senior Programs Mitigate It? Mathematics 2021, 9, 2003. https://doi.org/10.3390/ math9162003

Academic Editor: David Barilla

Received: 26 July 2021

Accepted: 20 August 2021

Published: 21 August 2021

Publisher's Note: MDPI stays neutral with regard to jurisdictional claims in published maps and institutional affiliations.

Copyright: (c) 2021 by the authors. Licensee MDPI, Basel, Switzerland. This article is an open access article distributed under the terms and conditions of the Creative Commons Attribution (CC BY) license (https:/ / creativecommons.org/licenses/by/ $4.0 /)$.

\begin{abstract}
Seasonality is a widely recognised and accredited phenomenon known to cause an imbalance in tourism activity throughout the year, prompting tourist destinations, both public and private, to consider how best to plan the use of their resources. One way of mitigating the economic imbalances that seasonality can cause is to find strategies for seasonal adjustment, such as travel programmes aimed at the elderly. This paper analyses the seasonality of tourism activity in some EU countries, and in particular in Spain. Different indicators are used to compare the results and carry out a sensitivity analysis. The study then focuses on tourism programmes for the elderly in Spain to see whether this type of programme helps to alleviate the seasonality of tourism activity. To corroborate this, an econometric model is specified and estimated, which enables the scope of these programmes to be compared.
\end{abstract}

Keywords: seasonality; tourism demand; tourism supply; Gini coefficient; social tourism

\section{Introduction}

Tourism seasonality is understood as the concentration of flows and tourist activity in a certain period of the year [1]. References [2,3] define seasonality in tourism activity as a temporary imbalance, in which both supply and demand are involved. It describes the temporary mismatch between supply and demand and the subsequent imbalances between the coming and going of tourists. According to [4], seasonality can be considered as having two dimensions: natural and institutional. Natural seasonality refers to variations caused by natural phenomena, such as the weather. Institutional or cultural seasonality is much more complex and is related to different factors, such as work holidays, school holidays, travel habits, religious holidays, tradition and the existence of sociocultural or sporting events, such as the opera season, music festivals and marathons.

Tourism seasonality has social, economic and environmental consequences, most of them negative [5]. Among the economic consequences are price increases during the high season, and the instability of income and employment of workers with repercussions on commitment and the quality of the services offered [6-9]. There are, however, some workers, such as those who combine work with study, who may benefit from the possibility of gaining extra income in certain seasons. Among the environmental consequences, the pressure of demand in the high season leads to pollution and the plundering of natural landscapes, although the seasonality of tourism activity does provide natural resources with a recovery period after the tourist season. Lastly, from a social perspective, the increase in pressure from a high tourist demand on facilities and infrastructures and on resources is felt by local residents. This leads, in some cases, to the rejection of tourism by the resident population. Likewise, the high demand for accommodation in certain periods reduces its availability and increases the price of housing. Finally, destinations with high seasonality tend to require lower educational levels in the working population, with the consequent impact on labour productivity and development. 
Seasonality is one of the most significant phenomena to affect tourism activity and, as mentioned earlier, has social, economic and environmental repercussions. This wide scope of issues has prompted a prolific amount of research, as shown in a review of the scientific literature. Among the many contributions worth mentioning are the studies by [7,10-22].

From a statistical point of view, there are many studies on the existence of seasonality in tourism activity. Most of the contributions focus on detecting the existence of seasonality through the analysis of indicators. From an economic point of view, studies focus on the consequences that seasonality has on productive activity. It is clear that studies which have quantified the consequences of seasonality are prolific $[7,11,14,16,20,22-27]$. Other studies have focused on offering solutions to seasonality [8,28-32]. Yet, other contributions analyse the factors that cause the seasonal behaviour of tourism activity $[18,33,34]$ since, depending on the factors that are behind seasonality, certain economic policy measures could be put in place to combat these factors.

As pointed out by [18], if seasonality responds to climatic or institutional factors, then the policies should be oriented towards stimulating demand in the low season. If, on the contrary, seasonality responds to economic factors, such as income, the relative price or the exchange rate, then the appropriate policies would need to aim at influencing economic factors. Recently, the COVID-19 pandemic is involving a review of the management and marketing strategies of tourism $[35,36]$. One last group of studies focuses on analysis of the effectiveness of economic policy measures aimed at reducing the seasonality of tourism activity and its adverse effects [6,37-42].

According to [5], tourist seasonality is a temporary imbalance caused mainly by a greater concentration of tourist flows at certain times of the year in which both demand and supply factors may play a part. These authors point out that measuring supply and demand is not the same thing, that an imbalance is often seen between supply and demand. Yet, supply is likely a consequence of demand, so the importance of analysing the former should not be underestimated. However, most of the studies have focused on analysing seasonality from the perspective of demand, without taking into account that equilibrium is achieved through the interaction between supply and demand [31]. Analysis of seasonality, therefore, is best approached from the perspective of both demand as well as supply. It is clear that one way to reduce the seasonality of a tourist destination is based on proposing attractive alternatives for periods of low demand. In this way, long-term jobs can be created, contributing to the social welfare of workers, their families and citizens, and in general, to the sustainability of this economic and social activity. In this sense, some works propose strategies based on innovation and well-being, on making use of rural environments or with specific characteristics, controlling the number of visitors so that the experience is adequate [43], or on providing a specific activity based on creativity and innovation, so that specific cultural traits of the host community are exploited [44,45].

Despite the interest in analysing the impact, implications and the proposals for managing seasonality in tourism activity, the complexity of the problem itself makes it difficult for those responsible for planning tourist destinations to reach a consensus on how best to tackle the problem.

The aim of this study is, on the one hand, to quantify the seasonality of tourism activity, both in terms of supply and demand and, on the other hand, to analyse and quantify the impact of applying seasonal adjustment measures, such as the programmes offered by the Institute for the Elderly and Social Services (Imserso). Data are used for different Spanish regions and also for specific European countries. To analyse the demand, the data of registered travellers in hotel establishments are considered, while analysis of supply examines the number of tourist accommodation establishments that are open. The data for Spain and its Autonomous Communities (AACC) come from the National Institute of Statistics of Spain (INE) and the Statistical Office of the European Union (Eurostat). The study of seasonality is carried out using different statistics, and use is made of the variation coefficient (VC) and the Gini coefficient (GC) for each of the years in the period considered. This allows the evolution of seasonality to be analysed in different tourist 
destinations in Spain, alongside a comparative study of Spain itself with other European tourist destinations. Other indicators are also applied that reflect the seasonality of the data and, subsequently, all the results obtained are compared to examine whether there are significant differences between them.

In order to examine the effectiveness of the programme developed by Imserso in reducing the seasonality of tourism activity in Spain, an econometric model is specified in which the endogenous variable is the variation of the GC of tourism activity in the Spanish regions and, as explanatory factors, the number of travellers in hotel establishments assigned to the Imserso Social Tourism Programme and the value of the subsidy of the programme. So, the contribution of this paper is to quantify the seasonality of tourism activity, both in terms of supply and demand, and, on the other hand, to analyse and quantify the impact of programmes for the elderly in Spain to see whether this type of programme helps to alleviate the seasonality of tourism activity.

The paper is organised as follows. After the introduction, Section 2 presents the data used. Section 3 describes the methodology and Section 4 analyses the results obtained. Finally, the last section, Section 5, offers the conclusions and proposes recommendations for economic and business policy to reduce the seasonality of tourist destinations.

\section{Data}

The information used comes essentially from three sources. For analysis of the international environment, Eurostat data are used for the time period from January 1999 to December 2019. For studying the seasonality of tourism activity in Spain, the INE provides the relevant data for the time period of January 2001 to December 2019. Finally, the information from Imserso is used to assess whether this tourism policy measure applied in Spain contributes to reducing the seasonality of activity of the tourism sector. We can note that the year 2020 is not considered in this study because, firstly, the irregular behaviour of the tourist campaign and its high volatility for this year; secondly, information about the Imserso programme is not available for this year. However, as noted above, we can indicate some works about tourism and the COVID-19 pandemic [35,36].

The indicator used in this study to measure tourism activity at an international level is the number of registered travellers in hotel establishments, boarding houses, hostels, rural houses and campsites (hereafter referred to collectively as hotel establishments). This information is then divided into three groups: tourists residing in the country itself, tourists residing in foreign countries, and total tourists. The European international tourist destinations considered are Germany, Austria, Spain, France, Holland, Italy, Portugal, the United Kingdom (UK) and Sweden. The choice of these destinations is not random, and it is due to two main reasons: (i) these regions are the most important destinations either for national or international tourism, and (ii) the tourist information about these destinations is available monthly, with the exception of France, but considering the importance of this tourist destination we opted for its inclusion in the work.

The study of seasonality for Spain is carried out from a double perspective. From the point of view of demand, the number of travellers in hotel establishments is used as an indicator. This indicator is divided into three groups: resident tourists, foreign tourists and total tourists. The six tourist destinations considered are the Autonomous Communities of Andalusia, the Balearic Islands, the Canary Islands, Catalonia, the Valencian Community and the Murcia Region. These tourist destinations were selected because they are the regions where the Imserso programme takes place and the regionalized information is recollected. We remark that there exist other regions in Spain with a notable tourist importance; however, these others regions do not present a notable seasonality. These are regions with other types of tourism that reduce the seasonality, for example in the Madrid Community there are several types of tourism: cultural, events or business. The absence of seasonality excludes these destinations from the Imserso Programme.

From the point of view of supply, the following indicators are considered, among others: the number of tourist establishments that are open, the hotel occupancy rate and 
the volume of personnel hired. In addition, other indicators include those related to profitability, such as the average hotel rate and the income per available room.

The Spanish government is aware of the significance of seasonality in tourism activity and the consequent repercussions on production and the labour market and has therefore decided on a set of measures to promote tourism in periods of less tourism activity. One of these initiatives is the Active Ageing Programme for the elderly offered by Imserso on which this study focuses.

The Active Ageing Programme, managed by Imserso, includes two programmes: the Social Tourism Programme and the Thermalism Programme. The Social Tourism Programme for the elderly, in operation since 1985, provides the elderly with the possibility of accessing holidays at a reduced price in areas with warm climates, and which offer localised cultural tours of places of interest. The beneficiaries of the programme are people residing in Spain aged 65 or over, state pensioners, widowed pensioners aged 55 years or over, other pensioners, early retirees and beneficiaries of unemployment benefits or subsidies- the latter three cases are for people aged 60 or over. Native Spanish people who are residents outside of Spain can also participate in the programme if they receive a pension from the Spanish Social Security System (See Appendix A for more details).

The main objectives of the programme are:

(1) To improve the quality of life of the elderly through tourism activities, connecting them with other environments and providing access to cultural assets.

(2) To favour the creation or maintenance of employment in the tourism sector, with particular attention given to the hotel sector, during low season, thereby helping to alleviate the seasonality of the sector.

(3) To promote productive activity in various sectors of the economy.

As mentioned earlier, one objective of this study is to verify whether this programme has, in fact, managed to reduce the seasonality of tourist destinations.

\section{Methodology}

In order to quantify the degree of seasonality in tourism activity, six different seasonality coefficients are used as measurements. These are the variation coefficients (VC), Gini (GC), Markham (MC), Walsh-Lawler (WLC), Oliver (OC) and Entropy (EC), whose formulas are set out below. It should be noted that these indices are used in most of the scientific literature that deals with tourism seasonality [11,18-22,34,41,46,47].

Aspects of notation and seasonality measures used are presented below to help with the correct interpretation of the results.

\subsection{Notation and Seasonality Coefficients}

In calculating the seasonality coefficients, it is important to take into account certain characteristics of the phenomenon analysed, such as its periodicity. The figures used in this study are monthly values for different years and for the different indicators of tourism activity considered, both for supply and demand. The value of the indicator considered in the month $i$ of year $j$ is denoted as $x_{i j}$; thus, $x_{j}=\sum_{i=1}^{12} x_{i j}$ represents the annual total of the tourism indicator for the year $j$, and the average monthly value for the year $j$ is $\overline{x_{j}}=\frac{\sum_{i=1}^{12} x_{i j}}{12}$. Similarly, the variance and standard deviation of the indicator are defined, as is usual, as $\sigma_{x_{j}}^{2}=\frac{\sum_{i=1}^{12}\left(x_{i j}-\bar{x}_{j}\right)^{2}}{12}$ and $\sigma_{x_{j}}=\sqrt{\sigma_{x_{j}}^{2}}$, respectively.

Each of the seasonality coefficients used in this study are detailed below:

- Variation coefficient (VC). This is a relative measure of variability that indicates the size of a standard deviation in relation to its mean. The expression of $\mathrm{VC}$ for the year $j$ is:

$$
\mathrm{VC}_{j}=\frac{\sqrt{\frac{\sum_{i=1}^{12}\left(x_{i j}-\bar{x}_{j}\right)^{2}}{12}}}{\bar{x}_{j}}=\frac{\sigma_{x_{j}}}{\bar{x}_{j}}
$$


If the indicator or variable used to measure tourism activity does not show seasonality, that is, it shows the same tourism activity every month, the VC is equal to zero (null standard deviation). On the contrary, if this coefficient takes a positive value, it will reflect a certain seasonality, although not every month will present the same volume of tourism activity. Consequently, the higher the coefficient of variation, the greater the seasonality of tourist flows.

- Gini coefficient (GC) [48]. Before calculating this, the values of the indicator of tourism activity needed to be ordered from lowest to highest value, within each year. Thus, the GC for year $j$ is calculated using the following expression:

$$
G C_{j}=\frac{\sum_{\mathrm{i}=1}^{12-1}\left(p_{i}-q_{i}\right)}{\sum_{i=1}^{12-1} p_{i}}
$$

where $p_{i}$ represents the cumulative percentage of the months of the year $(1 / 12,2 / 12, \ldots)$ and $q_{i}$ the accumulated percentage of the indicator of tourism activity in each of the months (rearranged) within year $j$. As can be seen in Equation (2), this coefficient calculates the differences between $p_{i}$ and $q_{i}$ only for the eleven months of the year with the lowest value, since, in the last month considered, which concentrates the highest accumulated volume of tourism activity, both amounts coincide. In this way, it is evident that, if there is no seasonality in a tourist destination, that is, if the tourist flow is the same each month, the coefficients $p_{i}$ and $q_{i}$ coincide in all months of the year, so the GC statistic would be equal to zero. On the contrary, if all tourism activity is concentrated in a single month, $i$, it is evident that, for that month, the value of $q_{i}$ would be equal to 1 , but for remaining months the $q_{i}$ coefficients would be equal to zero, so the GC would reach the value of 1 .

- Markham coefficient (MC) [49]. This is based on the so-called circular statistics, in which the values of each of the months are distributed over a circle positioned angularly according to the order they occupy and in a clockwise direction.

This coefficient assumes that the monthly values of tourism activity are vector magnitudes that, for the month $i$ of year $j$, are characterised by the pair $\left\{\theta_{i j}, x_{i j}\right\}$ so that they define a vector with the following properties: the vector module coincides with the magnitude of the tourism activity of the corresponding month, $x_{i j}$; furthermore, the month considered is characterised (on the circle) by an angle $\theta_{i j}$, proportional to the number of days elapsed from the beginning of the year to the middle of the month $i, t_{i j}$. This gives $\theta_{i j}=\frac{2 \pi}{365} t_{i j}$. With these properties, the coordinates of the vector that defines the value on $x_{i j}$ of the tourist indicator for month $i$ of year $j$ are $\left(x_{i j} \cos \left(\theta_{i j}\right), x_{i j} \operatorname{sen}\left(\theta_{i j}\right)\right), i=1, \ldots 12 ; j=2001, \ldots 2019$.

To calculate the annual seasonality of tourism activity in year $j$, the MC considers the vector resulting from the algebraic sum of the twelve-monthly vectors, that is, the vector $\left(C_{j}, S_{j}\right)$ defined by Equations (3) and (4).

$$
\begin{gathered}
C_{j}=\sum_{i=1}^{12} x_{i j} \cos \left(\theta_{i j}\right) \\
S_{j}=\sum_{i=1}^{12} x_{i j} \operatorname{sen}\left(\theta_{i j}\right)
\end{gathered}
$$

In year $j$, the calculation of this coefficient provides two magnitudes. The first magnitude, $R_{j}$, represents the degree/intensity of annual seasonality; the second magnitude, $\theta_{j}$, is related to the direction of the resulting vector and represents the mean time of occurrence or the concentration period of seasonality. Its values are obtained as follows:

$$
\begin{aligned}
R_{j} & =\sqrt{\left(S_{j}^{2}+C_{j}^{2}\right)} \\
\theta_{j} & =\tan ^{-1}\left(\frac{S_{j}}{C_{j}}\right)
\end{aligned}
$$


Thus, this coefficient is defined as the quotient between the resulting module $R_{j}$, and the total annual tourism activity $x_{j}$ :

$$
M C_{j}=\frac{R_{j}}{x_{j}}
$$

- Walsh-Lawler coefficient (WLC) [50]. This coefficient allows the variation in tourism activity to be quantified throughout each year $j$. Thus, this measure is based on the difference between the observed monthly tourism activity, $x_{i j}$, and the monthly average for the year, $\bar{x}_{j}$. This is expressed as:

$$
W L C_{j}=\frac{1}{x_{j}} \sum_{i=1}^{12}\left|x_{i j}-\bar{x}_{j}\right|
$$

Note that this coefficient varies between the zero value, if all the months register the same volume of tourism activity, and the maximum value $22 / 12=1.83$, which occurs when all the tourism activity takes place in a single month.

- Oliver coefficient (OC) [51]. This coefficient attempts to measure the intensity of the concentration of a magnitude by means of the quotient given in (9). Thus, considering monthly values of each year $j$ and defining $\ddot{p}_{i j}=\frac{x_{i j}}{x_{j}}$, the indicator is given by the following algebraic expression:

$$
O C_{j}=\frac{\sum_{i=1}^{12} \ddot{p}_{i j}^{2}}{\left(\sum_{i=1}^{12} \ddot{p}_{i j}\right)^{2}}
$$

The limits of this coefficient are minimum value 0.08 , when there is equidistribution, and maximum value 1 , in case of maximum concentration; only one of the periods registers a value different from 0 .

- Entropy coefficient of information or Shannon entropy (EC) [52]. This indicator tries to measure the order of the set of states of a system as a function of the probability of occurrence of each of them. When all the states have the same probability of occurrence, this is interpreted as the system presenting equidistribution, and this measure takes its maximum value (for the case of 12 states it is approximately 3.58). On the contrary, when one of the states has a probability of occurrence equal to 1 , this is interpreted as a maximum concentration, and the measure takes its minimum value, 0 . The algebraic expression of the EC of a system with $n$-states and with a probability of occurrence of each of them equal to $p_{n}$ is given by the expression $-\sum_{i=1}^{n} p_{i} \log _{2}\left(p_{i}\right)$. In the particular case of tourism activity and for monthly values of the corresponding indicators in year $j$, the following expression is given:

$$
E C_{j}=-\sum_{i=1}^{12} \ddot{p}_{i j} \log _{2}\left(\ddot{p}_{i j}\right)
$$

It is interesting to note that the base of the logarithm does not condition the results obtained, so the values of this indicator are equivalent regardless of the base used.

When using the different coefficients in the analysis, some facts about their variability field (range) need to be specified. Table 1 shows the ranges of variation of the coefficients considered so that these can be grouped around two blocks depending on the magnitude of their values. On the one hand, the Gini, Markham and Oliver coefficients take values between 0 and 1; on the other hand, the Variation, Walsh-Lawler and Entropy coefficients have a lower variation range than the previous ones but are similar in magnitude to each other (although not the same). In order for these coefficients to be expressed with a similar minimum and maximum value, certain modifications are introduced so that 
the values obtained maintain the order of the minimum equidistribution value and the maximum concentration value. Thus, Table 1 collects not only the variability fields of the coefficients considered, but also those of their modifications. Finally, it should be noted that the coefficients used, although they all quantify seasonality, measure different degrees of intensity. Likewise, although the degree of association between the coefficients is very high, the relationship between the values in pairs of coefficients considered is not linear in all cases.

Table 1. Field of variability of the different coefficients of seasonality.

\begin{tabular}{ccc}
\hline Coefficient & Minimum Value & Maximum Value \\
\hline Variation (VC) & 0 Equidistribution & $\sqrt{n-1}=\sqrt{11}=3.31$ \\
Gini (GC) & 0 Equidistribution & 1 maximum concentration \\
Markham (MC) & 0 Equidistribution & 1 maximum concentration \\
Oliver (OC) & 0.08 Equidistribution & 1 maximum concentration \\
Walsh-Lawler (WLC) & 0 Equidistribution & 1.83 maximum concentration \\
Entropy (EC) & maximum concentration & 3.58 Equidistribution \\
Oliver modified (OCM) & 0 Equidistribution & 1 maximum concentration \\
Walsh-Lawler modified (WLCM) & 0 Equidistribution & 3.66 maximum concentration \\
\hline
\end{tabular}

Source: compiled by the authors.

\subsection{Econometric Model}

In order to verify the effectiveness or validity of the tourism policy measures overseen by the Ministry of Social Rights and Agenda 2030 in Spain, through the Imserso Social Tourism Programme, an econometric model is specified to corroborate whether the programme has contributed to the reduction in seasonality in tourism activity in Spain.

The analysis is carried out both from the perspective of demand and also of supply. From the perspective of demand, the number of travellers in hotel establishments is used, while from the perspective of supply, the number of hotel establishments that are open is used, which reflects the capacity to receive tourists, in each of the tourist destinations considered.

The equation of the econometric model to analyse seasonality from the demand perspective is:

$$
\begin{gathered}
\log \left(G C_{d t}^{D}\right)=\beta_{1} \log \left(G C_{d t-1}^{D}\right)+\beta_{2} \log \left(V_{I M S d t}\right)+\beta_{3} \log \left(V_{\text {IMS } d t-1}\right)+ \\
+\beta_{4} \log \left(P_{\text {IMS } d t}\right)+\beta_{5} \log \left(P_{\text {IMS } d t-1}\right)+\sum_{d=1}^{6} \gamma_{d} D T U R_{d}+u_{d t}
\end{gathered}
$$

The variable $G C_{d t}^{D}$ measures the degree or intensity of seasonality of each of the tourist destinations, $(d=1,2, \ldots, 6)$, throughout the entire period analysed, which goes from 2001 to $2019,(t=1,2, \ldots, 19)$. This gives 114 observations for the variable $G C_{d t}^{D}$, when considering the six tourist destinations over the nineteen-year period. Thus, the variable intensity of seasonality is quantified by the number of total travellers in hotel establishments $\left(G C_{d t}^{D}\right)$.

The efficiency of the Imserso programme is measured through two variables. The first variable, denoted as $V_{I M S}$ t , corresponds to the number of beneficiaries or travellers in hotel establishments subsidised by Imserso. The information available on this variable is annual data for the six tourist destinations considered. The second variable used, $P_{I M S} d t d t$, represents the value of the subsidy by Imserso. In order to homogenise the price variable, throughout the sample period, it has been deflated using the CPI of hotel establishments and restaurants.

From the economic point of view, the regression coefficient obtained for the variable number of travellers in hotel establishments subsidised by Imserso is expected to present a negative sign. This indicates that, as the number of travellers increases in periods of low tourist demand, the intensity of seasonality decreases. However, the regression coefficient that affects the variable value of the subsidy is also expected to present a negative sign, since 
when the value of the subsidy decreases, there will be less demand on the part of the potential beneficiaries of the programme, causing an increase in the degree of seasonality.

Lastly, the variables $D T U R_{d}$, which are six dummy variables, collect the effect in each of the tourist destinations. Thus, each one of them takes the value 1 according to the corresponding tourist destination, and 0 in the other cases.

The econometric model specified to analyse seasonality from the supply point of view is:

$$
\begin{gathered}
\log \left(C G_{d t}^{O}\right)=\beta_{1} \log \left(C G_{d t-1}^{O}\right)+\beta_{2} \log \left(V_{I M S d t}\right)+\beta_{3} \log \left(V_{I M S d t-1}\right)+ \\
+\beta_{4} \log \left(P_{I M S d t}\right)+\beta_{5} \log \left(P_{I M S d t-1}\right)+\sum_{d=1}^{6} \gamma_{d} D T U R_{d}+u_{d t}
\end{gathered}
$$

The variable $G C_{d t}^{O}$ measures the intensity of seasonality from the point of view of supply and for each of the tourist destinations, $(d=1,2, \ldots, 6)$, throughout the period under analysis, which goes from 2001 to 2019; $(t=1,2, \ldots, 19)$. Thus, there are 114 observations for the variable $G C_{d t}^{O}$, which quantify the number of hotel establishments that are open throughout the nineteen years considered for the six tourist destinations. The variables $V_{I M S d m t}, P_{I M S d m t}$ and $D T U R_{d}$ have been explained previously.

From the economic point of view, the regression coefficient of the variable number of travellers in the hotel establishments subsidised by Imserso is expected to show a negative sign, indicating that the seasonality of the supply is reduced in the face of an increase in travellers. The regression coefficient that affects the variable value of the subsidy is expected to also be negative, since increasing subsidies would produce a greater supply for hotel establishments, causing a decrease in the intensity of seasonality.

\section{Results}

\subsection{International Context}

From the information obtained on the number of travellers in hotel establishments for the different EU countries considered, it can be seen that the countries which have a greater tourist market are Germany, France, Spain, Italy and Great Britain. However, analysis of the two market segments - that of the number of domestic travellers and the number of foreign travellers-shows that in Germany, France and Great Britain, domestic tourism is more important than foreign tourism. On the contrary, in Italy and Spain, foreign tourism is more relevant (see Table 2).

Table 2. Travel to hotel establishments in EU countries.

\begin{tabular}{ccccccccccc}
\hline \multicolumn{10}{c}{ Total Number of Travellers Staying in Hotel Establishments (Millions) } \\
\hline Year & EU * & Germany & Austria & Spain & France & Holland & Italy & Portugal & UK & Sweden \\
\hline 2008 & 762.79 & 131.04 & 28.84 & 100.09 & n.a. & 29.17 & 94.51 & 14.34 & 89.53 & 22.46 \\
2009 & 692.39 & 127.57 & 28.57 & 93.89 & n.a. & 29.08 & 95.50 & 13.87 & 88.46 & 22.80 \\
2010 & 681.41 & 134.56 & 29.70 & 99.17 & n.a. & 30.01 & 98.48 & 14.44 & 88.00 & 23.43 \\
2011 & 736.74 & 141.74 & 30.91 & 103.08 & 148.95 & 30.76 & 103.72 & 14.81 & 92.22 & 23.99 \\
2012 & 751.25 & 147.30 & 32.33 & 100.41 & 149.08 & 31.15 & 103.73 & 14.65 & 103.67 & 23.87 \\
2013 & 770.67 & 149.69 & 32.94 & 101.67 & 153.69 & 34.05 & 103.86 & 15.90 & 106.80 & 24.61 \\
2014 & 798.96 & 155.19 & 33.65 & 107.47 & 152.96 & 36.12 & 106.55 & 17.99 & 102.58 & 25.85 \\
2015 & 839.41 & 161.16 & 35.36 & 114.27 & 157.59 & 37.24 & 113.39 & 18.12 & 107.77 & 27.49 \\
2016 & 876.74 & 165.62 & 37.09 & 123.54 & 157.33 & 38.88 & 116.94 & 21.92 & 101.62 & 29.10 \\
2017 & 927.97 & 172.32 & 38.59 & 129.36 & 166.84 & 42.24 & 123.20 & 24.56 & 109.30 & 29.69 \\
2018 & 962.13 & 179.24 & 40.09 & 130.81 & 171.48 & 43.91 & 127.11 & 25.87 & 111.44 & 30.84 \\
2019 & 1006.00 & 185.12 & 41.32 & 134.71 & 180.72 & 45.92 & 131.38 & 27.90 & 117.29 & 31.90 \\
\hline
\end{tabular}


Table 2. Cont.

\begin{tabular}{|c|c|c|c|c|c|c|c|c|c|c|}
\hline \multicolumn{11}{|c|}{ Structure in the EU of National Travellers Staying in Hotel Establishments (\%) } \\
\hline Year & EU * & Germany & Austria & Spain & France & Holland & Italy & Portugal & UK & Sweden \\
\hline 2008 & 100.00 & 24.41 & 2.24 & 12.96 & n.a. & 4.36 & 12.12 & 1.69 & 15.85 & 4.08 \\
\hline 2009 & 100.00 & 24.51 & 2.38 & 12.96 & n.a. & 4.52 & 12.88 & 1.77 & 16.42 & 4.25 \\
\hline 2010 & 100.00 & 25.36 & 2.47 & 13.13 & n.a. & 4.50 & 12.86 & 1.81 & 15.88 & 4.35 \\
\hline 2011 & 100.00 & 24.56 & 2.32 & 11.97 & 23.20 & 4.20 & 12.18 & 1.64 & 15.34 & 4.11 \\
\hline 2012 & 100.00 & 25.03 & 2.38 & 11.19 & 22.82 & 4.18 & 11.77 & 1.53 & 17.81 & 4.05 \\
\hline 2013 & 100.00 & 25.04 & 2.36 & 10.99 & 22.81 & 4.50 & 11.35 & 1.59 & 17.45 & 4.15 \\
\hline 2014 & 100.00 & 25.13 & 2.34 & 11.33 & 21.96 & 4.55 & 11.29 & 1.70 & 15.79 & 4.19 \\
\hline 2015 & 100.00 & 24.80 & 2.32 & 11.56 & 21.74 & 4.40 & 11.46 & 1.60 & 15.73 & 4.20 \\
\hline 2016 & 100.00 & 24.56 & 2.34 & 11.73 & 21.19 & 4.35 & 11.35 & 1.81 & 14.40 & 4.25 \\
\hline 2017 & 100.00 & 24.41 & 2.29 & 11.60 & 21.32 & 4.40 & 11.33 & 1.85 & 14.68 & 4.13 \\
\hline 2018 & 100.00 & 24.66 & 2.30 & 11.41 & 20.88 & 4.41 & 11.31 & 1.90 & 14.59 & 4.13 \\
\hline 2019 & 100.00 & 24.44 & 2.24 & 11.25 & 21.34 & 4.33 & 11.13 & 1.96 & 14.79 & 4.11 \\
\hline \multicolumn{11}{|c|}{ Structure in the EU of Foreign Travellers Staying in Hotel Establishments (\%) } \\
\hline Year & $\mathbf{E U} *$ & Germany & Austria & Spain & France & Holland & Italy & Portugal & UK & Sweden \\
\hline 2008 & 100.00 & 7.58 & 5.82 & 13.34 & n.a. & 3.11 & 12.75 & 2.13 & 6.27 & 1.44 \\
\hline 2009 & 100.00 & 8.93 & 6.86 & 14.50 & n.a. & 3.70 & 15.22 & 2.37 & 7.09 & 1.80 \\
\hline 2011 & 100.00 & 10.29 & 7.34 & 17.38 & 15.21 & 4.14 & 17.27 & 2.64 & 7.77 & 1.82 \\
\hline 2012 & 100.00 & 10.68 & 7.47 & 16.94 & 14.94 & 4.10 & 17.17 & 2.64 & 7.21 & 1.74 \\
\hline 2013 & 100.00 & 10.54 & 7.30 & 16.68 & 15.41 & 4.28 & 16.84 & 2.81 & 8.17 & 1.69 \\
\hline 2014 & 100.00 & 10.53 & 7.12 & 16.76 & 14.75 & 4.48 & 16.53 & 3.12 & 8.24 & 1.75 \\
\hline 2015 & 100.00 & 10.56 & 7.14 & 16.78 & 14.20 & 4.50 & 16.68 & 3.02 & 8.37 & 1.85 \\
\hline 2016 & 100.00 & 10.22 & 7.12 & 17.70 & 12.98 & 4.57 & 16.38 & 3.56 & 7.29 & 1.89 \\
\hline 2017 & 100.00 & 9.95 & 6.91 & 17.40 & 13.05 & 4.78 & 16.14 & 3.81 & 7.50 & 1.83 \\
\hline 2018 & 100.00 & 9.88 & 6.88 & 16.77 & 13.38 & 4.79 & 15.98 & 3.83 & 7.22 & 1.86 \\
\hline 2019 & 100.00 & 9.62 & 6.82 & 16.50 & 13.06 & 4.91 & 15.86 & 3.95 & 7.10 & 1.81 \\
\hline
\end{tabular}

* 27 countries. Source: compiled by the authors using data from Eurostat.

Analysis of the historical evolution of the number of travellers staying in hotel establishments shows that the EU as a whole did not recover until 2013 from the economic crisis of 2008. However, it should be noted that the behaviour regarding the recovery of each country was uneven; in Sweden, for example, the 2008 economic crisis had practically no impact, while in other countries, such as Spain and the United Kingdom, it took several years to recover the lost level of tourism activity (see Table 2).

As can be deduced from Table 3, the problem of seasonality in tourism activity is an issue that affects all the European countries analysed. Considering the segmentation of the tourism market (see Table A1 of Appendix B), the highest intensity of seasonality in the national market, measured through the Gini coefficient, occurs in the United Kingdom, Sweden, Italy, France, Spain and Portugal.

In the international market, the problem of seasonality is essentially centred on Sweden, Italy, France and Spain. Interestingly, in Sweden, where the relative importance of tourism is not very high, the observed seasonality, measured through the Gini coefficient of the number of foreign travellers staying in hotel establishments, is the highest (see Table A2 of Appendix B). 
Table 3. Gini coefficient of total travellers staying in hotel establishments in the EU.

\begin{tabular}{cccccccccc}
\hline Year & Germany & Austria & Spain & France & Holland & Italy & Portugal & UK & Sweden \\
\hline 2001 & 0.13 & 0.11 & 0.18 & n.a. & 0.17 & 0.22 & 0.22 & 0.18 & 0.23 \\
2002 & 0.13 & 0.11 & 0.18 & n.a. & 0.17 & 0.22 & 0.22 & 0.15 & 0.24 \\
2003 & 0.15 & 0.12 & 0.19 & n.a. & 0.18 & 0.22 & 0.22 & 0.16 & 0.25 \\
2004 & 0.13 & 0.11 & 0.18 & n.a. & 0.16 & 0.21 & 0.21 & 0.14 & 0.29 \\
2005 & 0.13 & 0.10 & 0.18 & n.a. & 0.15 & 0.21 & 0.21 & 0.17 & 0.29 \\
2006 & 0.13 & 0.10 & 0.18 & n.a. & 0.15 & 0.21 & 0.21 & 0.17 & 0.25 \\
2007 & 0.12 & 0.10 & 0.17 & n.a. & 0.13 & 0.21 & 0.21 & 0.17 & 0.27 \\
2008 & 0.12 & 0.10 & 0.17 & n.a. & 0.14 & 0.21 & 0.21 & 0.18 & 0.23 \\
2009 & 0.13 & 0.10 & 0.18 & n.a. & 0.14 & 0.22 & 0.22 & 0.19 & 0.24 \\
2010 & 0.14 & 0.10 & 0.19 & n.a. & 0.15 & 0.22 & 0.22 & 0.19 & 0.23 \\
2011 & 0.13 & 0.10 & 0.20 & 0.20 & 0.14 & 0.23 & 0.23 & 0.18 & 0.23 \\
2012 & 0.13 & 0.10 & 0.19 & 0.19 & 0.14 & 0.23 & 0.23 & 0.17 & 0.22 \\
2013 & 0.13 & 0.10 & 0.20 & 0.20 & 0.16 & 0.23 & 0.23 & 0.19 & 0.22 \\
2014 & 0.13 & 0.10 & 0.20 & 0.20 & 0.15 & 0.24 & 0.24 & 0.20 & 0.22 \\
2015 & 0.13 & 0.11 & 0.19 & 0.21 & 0.15 & 0.24 & 0.24 & 0.18 \\
2016 & 0.12 & 0.11 & 0.19 & 0.20 & 0.14 & 0.23 & 0.23 & 0.17 & 0.22 \\
2017 & 0.12 & 0.11 & 0.19 & 0.19 & 0.13 & 0.23 & 0.23 & 0.18 & 0.23 \\
2018 & 0.12 & 0.10 & 0.18 & 0.19 & 0.13 & 0.22 & 0.22 & 0.17 \\
2019 & 0.12 & 0.11 & 0.18 & 0.20 & 0.13 & 0.22 & 0.22 & 0.18 & 0.19 \\
\hline
\end{tabular}

Source: compiled by the authors using data from Eurostat.

\subsection{National Context: Demand}

Initial results of the evolution of tourism activity for the whole of Spain suggest that both the group of foreign travellers and domestic travellers have maintained a high secular trend which has grown homogeneously throughout the entire period analysed, apart from the years 2009 and 2010 (see Figure 1). Indeed, as shown in Table 2, the number of travellers staying in hotel establishments suffers a significant decrease in 2009, due to the economic crisis of 2008, and recovery of tourism activity does not occur until 2011.

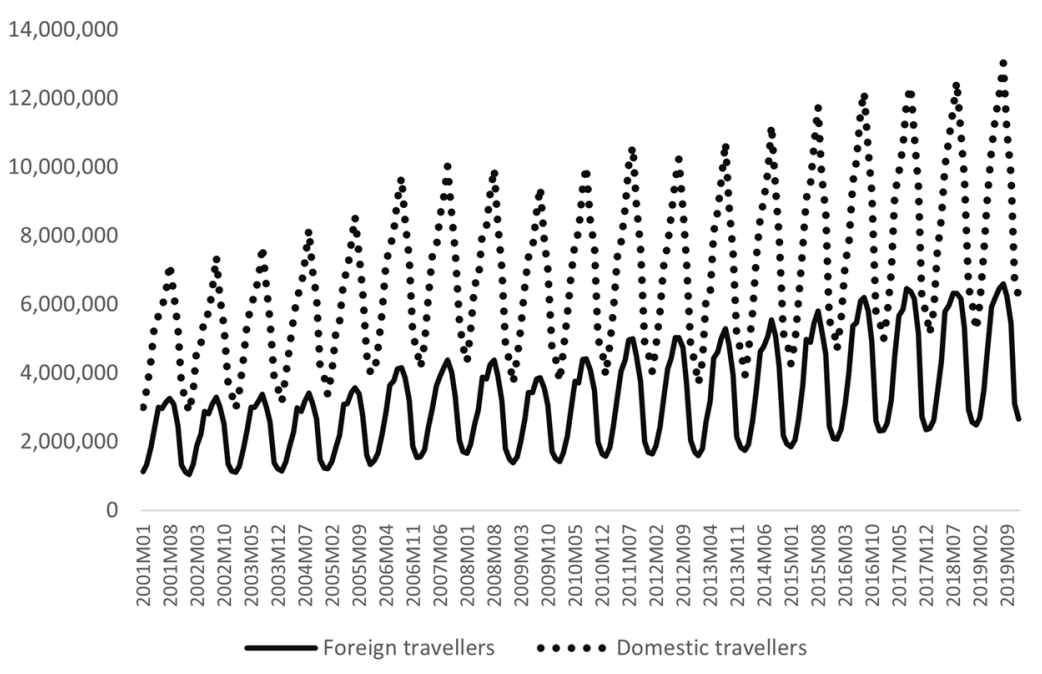

Figure 1. Number of travellers in hotel establishments in Spain. Source: compiled by the authors using data from INE.

When analysing seasonality for the different groups through the Gini coefficient (see Table 3, Tables A1 and A2 of Appendix B), Spain is seen to suffer higher seasonality than the EU as a whole. Furthermore, the 2008 economic crisis had a significant effect on seasonality by increasing a temporary concentration of travellers in the peak months of tourism activity in Spain. 
In order to analyse in depth the behaviour of the different seasonality coefficients used, the simple correlation between pairs of coefficients is calculated, the results of which are shown in Table 4 . The results indicate that the seasonality coefficients GC, WLC and VC provide similar information, and the EC (It should be noted that EC has a different sign in the correlation matrix because its valuation is inverse to the rest of the indices, that is, the value 0 indicates maximum concentration and its maximum value (3.58) indicates equidistribution) and the OC coefficients also provide very similar results. Thus, the statistical sensitivity analysis of the different seasonality coefficients suggests that the use of any one of them is valid.

Table 4. Simple correlation coefficients between the coefficients of the seasonality of demand (indicator: number of total travellers in hotel establishments).

\begin{tabular}{ccccccc}
\hline Year & VC & EC & GC & MC & OC & WLC \\
\hline VC & 1.00 & -0.97 & 1.00 & 0.99 & 0.97 & 0.99 \\
EC & -0.97 & 1.00 & -0.97 & -0.96 & -0.99 & -0.97 \\
GC & 1.00 & -0.97 & 1.00 & 0.99 & 0.97 & 0.99 \\
MC & 0.99 & -0.96 & 0.99 & 1.00 & 0.97 & 0.99 \\
OC & 0.97 & -0.99 & 0.98 & 0.97 & 1.00 & 0.98 \\
WLC & 0.99 & -0.98 & 0.99 & 0.99 & 0.98 & 1.00 \\
\hline
\end{tabular}

Source: compiled by the authors using data from INE.

As mentioned earlier, the coefficients considered do not have exactly the same range of values (see Table 1), which can give rise to some confusion. To correct this, some of the coefficients have been linearly transformed (the interpretation does not change) so that the ranges obtained are now comparable. Furthermore, the different seasonality coefficients used measure different characteristics of seasonality as a function of skewness and kurtosis.

Figure 2 shows the diagrams of the different seasonality coefficients. Through the information collected in Table 4 and Figure 2, it can be deduced that the GC, VC, MC and WLC coefficients have a similar behaviour. However, the OC and the EC coefficients, although they present a high level of correlation with the other coefficients considered, show a curvilinear relationship between them. Additionally, GC presents a positive association with OC, while, on the contrary, it presents a negative association with EC. In order to simplify the presentation of results, taking into account the high correlation between the coefficients and that GC is the coefficient most used in the scientific literature, this is the coefficient that has been selected to carry out the different analyses of the tourist indicators, both for supply and demand.

Analysis of seasonality for the different groups in hotel establishments-total travellers, national travellers and foreign travellers (see Tables A3 and A4 of Appendix B)leads us to conclude that seasonality is significantly higher in the group of foreign travellers in Spain than in the group of national travellers. Interestingly, the intensity of seasonality throughout the period analysed, for the whole of Spain and for both groups, has remained practically constant for all years in the period studied. However, it is clear that the 2008 economic crisis had an effect on seasonality, increasing the monthly seasonal concentration of tourism activity in the group of foreign travellers staying in hotel establishments (see Table A4 of Appendix B).

The study of seasonality by tourist destination in Spain provides mixed results. Indeed, when analysing the average seasonality coefficient (not to be confused with the seasonal variation coefficient. The average seasonality coefficient attempts to quantify the average seasonal movement within each year for each of the months considered in relation to the expected trend value) for the period studied for each of the six tourist destinations (see Table 5 and Figure 3), the tourist destination with the most marked seasonality is that of the Balearic Islands, followed by Catalonia. On the contrary, the Canary Islands tourist destination shows hardly any seasonality. 
Gini - Variation coefficient

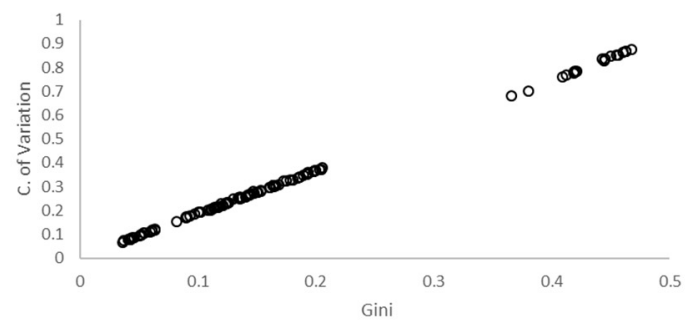

Gini - Markham

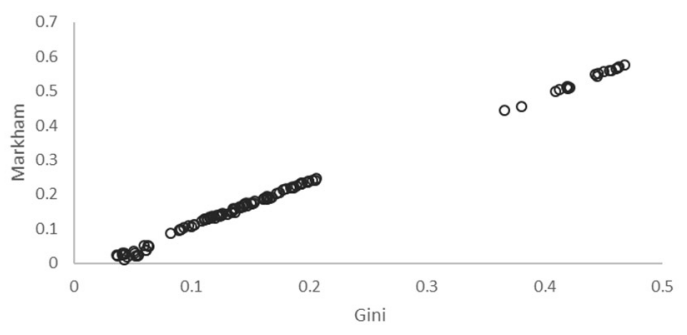

Gini - Walsh Lawler Modified

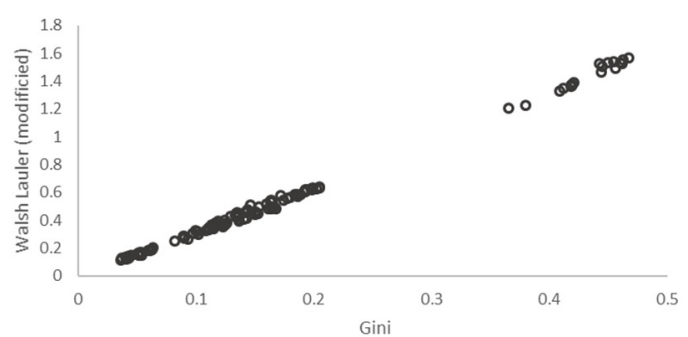

Gini - Entropy

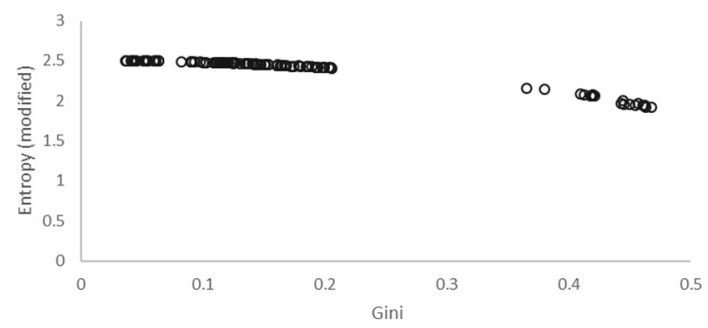

Gini - Oliver Modified

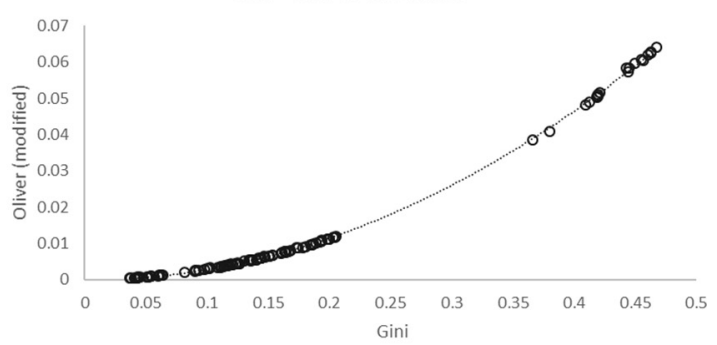

Entropy - Oliver Modified

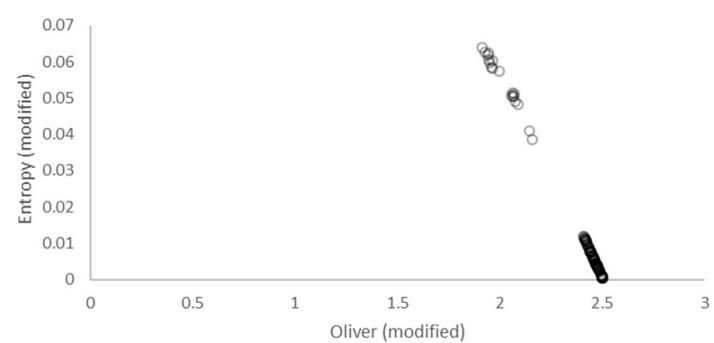

Figure 2. Diagram between different coefficients of seasonality. Source: compiled by the authors using data from INE and Eurostat.

Table 5. Gini coefficient of total travellers in hotel establishments.

\begin{tabular}{cccccccc}
\hline Year & Spain & Andalusia & $\begin{array}{c}\text { Balearic } \\
\text { Islands }\end{array}$ & $\begin{array}{c}\text { Canary } \\
\text { Islands }\end{array}$ & Catalonia & $\begin{array}{c}\text { Valencian } \\
\text { Community }\end{array}$ & $\begin{array}{c}\text { Murcia } \\
\text { Region }\end{array}$ \\
\hline 2001 & 0.15 & 0.13 & 0.37 & 0.04 & 0.19 & 0.12 & 0.10 \\
2002 & 0.15 & 0.13 & 0.38 & 0.05 & 0.19 & 0.12 & 0.10 \\
2003 & 0.16 & 0.13 & 0.41 & 0.05 & 0.19 & 0.14 & 0.09 \\
2004 & 0.15 & 0.12 & 0.42 & 0.06 & 0.18 & 0.12 & 0.08 \\
2005 & 0.16 & 0.12 & 0.42 & 0.06 & 0.19 & 0.12 & 0.09 \\
2006 & 0.15 & 0.14 & 0.41 & 0.06 & 0.19 & 0.12 & 0.09 \\
2007 & 0.15 & 0.14 & 0.42 & 0.06 & 0.19 & 0.13 & 0.09 \\
2008 & 015 & 0.15 & 0.42 & 0.04 & 0.19 & 0.14 & 0.10 \\
2009 & 0.16 & 0.16 & 0.42 & 0.05 & 0.19 & 0.14 & 0.12 \\
2010 & 0.16 & 0.16 & 0.44 & 0.06 & 0.19 & 0.15 & 0.11 \\
2011 & 0.17 & 0.16 & 0.46 & 0.05 & 0.21 & 0.16 & 0.12 \\
2012 & 0.17 & 0.16 & 0.46 & 0.04 & 0.19 & 0.17 & 0.11 \\
2013 & 0.18 & 0.17 & 0.46 & 0.05 & 0.19 & 0.17 & 0.13 \\
2014 & 0.18 & 0.17 & 0.47 & 0.05 & 0.19 & 0.16 & 0.11 \\
2015 & 0.17 & 0.16 & 0.46 & 0.04 & 0.19 & 0.16 & 0.12 \\
2016 & 0.17 & 0.15 & 0.45 & 0.04 & 0.19 & 0.15 & 0.11 \\
2017 & 0.16 & 0.15 & 0.45 & 0.04 & 0.19 & 0.15 & 0.11 \\
2018 & 0.16 & 0.14 & 0.44 & 0.04 & 0.18 & 0.14 & 0.10 \\
2019 & 0.16 & 0.14 & 0.45 & 0.04 & 0.18 & 0.14 & 0.11 \\
\hline
\end{tabular}

Source: compiled by the authors using data from INE. 


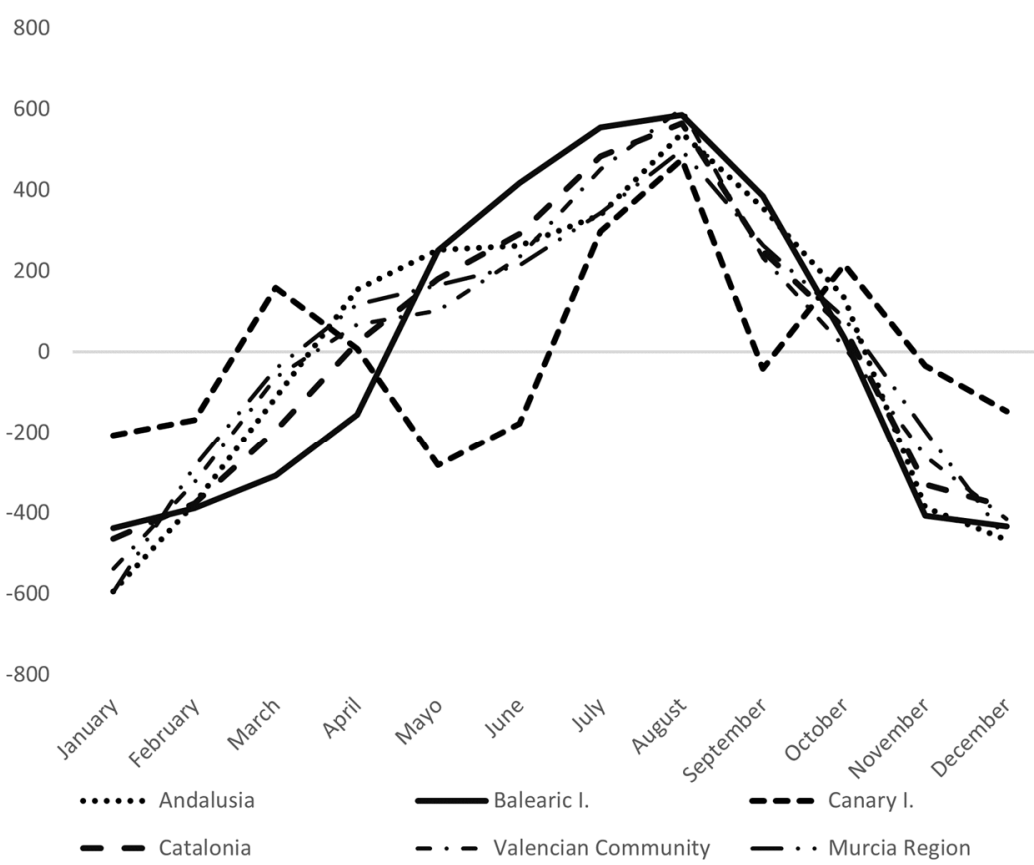

Figure 3. Average seasonality coefficient of total travellers. Source: compiled by the authors using data from INE.

Looking more closely at the study of the evolution of seasonality, from the perspective of demand, a model is specified in order to test whether the evolution of seasonality in the different destinations presents some kind of pattern. A model is specified to study the $\beta$-Convergence [53] for each of the tourist destinations, through the following equation:

$$
\log \left(G C_{d t}\right)-\log \left(G C_{d t-1}\right)=\omega+\beta \log \left(G C_{d t-1}\right)+u_{d t}
$$

The results of the estimates of Equation (13), shown in Table 6, suggest that the Balearic Islands are the only tourist destination that present a clear pattern of seasonality, statistically significant, at $99 \%$ probability. Catalonia shows a significant pattern at $95 \%$ probability and the other destinations considered do not exhibit behaviour which reflects a seasonal pattern.

Table 6. $\beta$-Convergence of the demand in each tourist destination. Source: compiled by the authors.

\begin{tabular}{cccc}
\hline Region & $\omega$ & $\beta$-Convergence & $\mathbf{R}^{2}$ \\
\hline Andalusia & -0.25 & -0.13 & 0.08 \\
Balearic Islands & $-0.19^{* * *}$ & $-0.25^{* * *}$ & 0.38 \\
Canary Islands & -1.01 & -0.33 & 0.14 \\
Catalonia & $-0.74^{* *}$ & $-0.45^{* *}$ & 0.17 \\
Valencian Community & -0.29 & -0.16 & 0.11 \\
Murcia Region & -0.61 & -0.27 & 0.13 \\
\hline
\end{tabular}

Note: ${ }^{* *}$ and ${ }^{* * *}$ probabilistically significant at $95 \%$ and $90 \%$, respectively.

Individual analysis of each of the tourist destinations shows that Andalusia has a lower intensity of seasonality for all total travellers in hotel establishments than that registered for the average for Spain throughout the period analysed (see Table 5). In Andalusia, the segment of foreign tourists presents higher seasonality than that of national tourists (see Table A3 of Appendix B). However, the intensity of seasonality of national tourists is higher than that registered in the whole of Spain. On the contrary, for the group of foreign tourists, the intensity of seasonality in Andalusia is lower than that registered in Spain (see Table A4 of Appendix B). 
The tourist destination of the Balearic Islands is characterised by high seasonality in the three tourist segments analysed (see Table 5, Tables A3 and A4 of Appendix B), in particular, in the group of foreign travellers in hotel establishments. Furthermore, the intensity of seasonality in this segment of tourists is much greater than in that of domestic tourists. It should be noted that the economic crisis of 2008 had a negative effect on seasonality, with its intensity increasing from 2010 onwards in the three groups of tourists. In all the cases analysed, seasonality for this tourist destination represents a significant imbalance.

For the tourist destination of the Canary Islands, seasonality in the segments of total travellers and foreign travellers in hotel establishments is irrelevant (see Table 5, Table A4 of Appendix B). For the group of national travellers, the intensity of its seasonality is higher than that registered for the group of national tourists in Spain (see Table A3 of Appendix B).

Catalonia is characterised by high seasonality in the three tourist segments analysed (see Table 5, Tables A3 and A4 of Appendix B). In all three cases, seasonality is higher than that registered for the whole of Spain. In addition, the intensity of seasonality in the segment of foreign travellers is higher than for the segment of domestic tourists.

The Valencian Community tourist destination is characterised as showing seasonality in the segments made up of total travellers and foreign travellers in hotel establishments, which is lower than the average seasonality registered for Spain (see Table 5, Table A4 of Appendix B). However, the intensity of seasonality in national tourists visiting the Valencian Community is higher than that registered in the whole of Spain (see Table A3 of Appendix B). Additionally, seasonality has increased in this segment since the economic crisis of 2008.

Lastly, the Murcia Region tourist destination is characterised as having a seasonal intensity lower than the average intensity of Spain (see Table 5). All three groups of tourists show an intensity of seasonality lower than the average registered in Spain (see Tables A3 and A4 of Appendix B).

\subsection{National Context: Supply}

The supply indicator, the number of hotel establishments that are open in Spain, shows a very regular pattern in its behaviour throughout the period analysed, which is indicative of the presence of seasonality (see Figure 4).

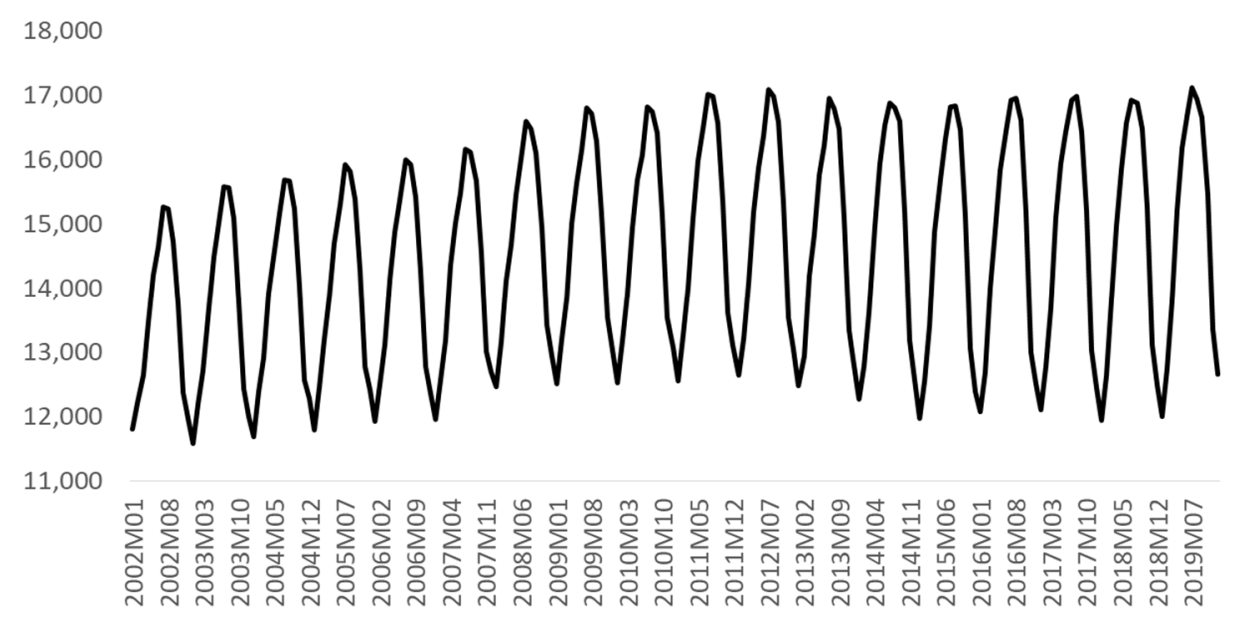

Figure 4. Number of hotel establishments that are open in Spain. Source: compiled by the authors using data from INE.

The study of seasonality, using the Gini coefficient, indicates that seasonality is very high in the tourist destination of the Balearic Islands. Indeed, when analysing the average seasonality coefficient of the period under study of the six tourist destinations (see Figure 5), the only destination that presents a marked seasonality is seen to be the Balearic Islands. The other tourist destinations show practically no seasonality. 


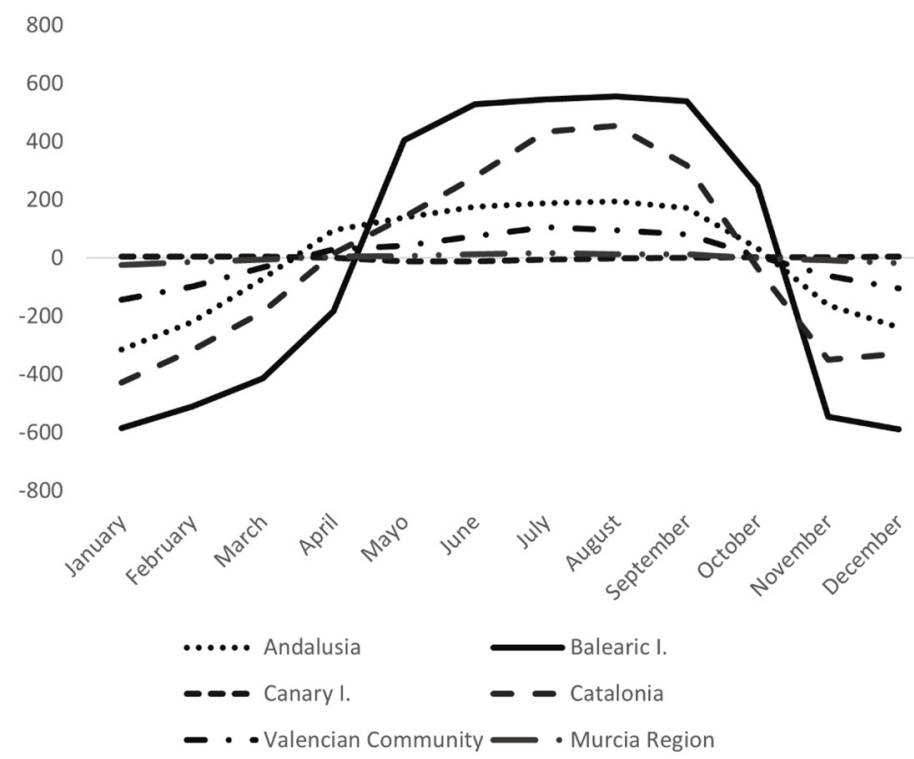

Figure 5. Coefficient of average seasonality of hotel establishments that are open. Source: compiled by the authors using data from INE.

Table 7 shows the simple correlation coefficients between pairs of seasonality coefficients for the indicator number of hotel establishments that are open. These results show that the seasonality coefficients GC, WLC and VC provide similar information. The coefficients $\mathrm{CE}$ and the $\mathrm{OC}$ also provide very similar results. Thus, the statistical sensitivity analysis of the different seasonality coefficients suggests, once again, equivalence in the use of any one of them.

Table 7. Simple correlation coefficient matrix between the different seasonality coefficients applied to the supply indicator. Source: compiled by the authors using data from INE.

\begin{tabular}{ccccccc}
\hline Variables & VC & EC & GC & MC & OC & WLC \\
\hline VC & 1.00 & -0.97 & 1.00 & 1.00 & 0.97 & 1.00 \\
EC & -0.97 & 1.00 & -0.96 & -0.97 & -0.99 & -0.97 \\
GC & 1.00 & -0.96 & 1.00 & 1.00 & 0.97 & 0.99 \\
MC & 1.00 & -0.97 & 1.00 & 1.00 & 0.97 & 0.99 \\
OC & 0.97 & -0.99 & 0.97 & 0.97 & 1.00 & 0.98 \\
WLC & 1.00 & -0.97 & 0.99 & 0.99 & 0.98 & 1.00 \\
\hline
\end{tabular}

Table 8 shows the evolution of the GC for the indicator supply, i.e., the number of hotel establishments that are open. It can be seen that, for the whole of Spain, this indicator shows hardly any seasonality. However, by tourist destinations, the only destination with high seasonality is the Balearic Islands. In addition, from an evolutionary point of view, seasonality in the Balearic Islands is seen to increase up until 2015, stabilising thereafter.

To look in more detail at the evolution of seasonality, from the supply perspective, the $\beta$-Convergence is estimated for each of the six tourist destinations considered. In effect, Equation (13) is used to check whether the evolution of seasonality in the different destinations presents some kind of pattern. The results of the estimates of Equation (13), presented in Table 9, suggest that the only tourist destination that presents a seasonal pattern, statistically significant at $99 \%$ probability, is the Balearic Islands. Interestingly, the tourist destination of the Canary Islands is characterised by presenting a totally volatile behaviour, since the $\beta$-Convergence is greater than 1 . Lastly, the other destinations considered do not present seasonal behaviour. 
Table 8. Gini coefficient of the hotel establishments that are open by destination. Source: compiled by the authors using data from INE.

\begin{tabular}{cccccccc}
\hline Year & Spain & Andalusia & $\begin{array}{c}\text { Balearic } \\
\text { Islands }\end{array}$ & $\begin{array}{c}\text { Canary } \\
\text { Islands }\end{array}$ & Catalonia & $\begin{array}{c}\text { Valencian } \\
\text { Community }\end{array}$ & $\begin{array}{c}\text { Murcia } \\
\text { Region }\end{array}$ \\
\hline 2001 & 0.04 & 0.02 & 0.25 & 0.00 & 0.09 & 0.04 & 0.00 \\
2002 & 0.06 & 0.03 & 0.36 & 0.01 & 0.10 & 0.04 & 0.04 \\
2003 & 0.06 & 0.04 & 0.38 & 0.01 & 0.11 & 0.06 & 0.03 \\
2004 & 0.06 & 0.04 & 0.38 & 0.01 & 0.11 & 0.05 & 0.03 \\
2005 & 0.06 & 0.04 & 0.38 & 0.01 & 0.10 & 0.05 & 0.04 \\
2006 & 0.06 & 0.04 & 0.38 & 0.01 & 0.10 & 0.05 & 0.05 \\
2007 & 0.06 & 0.04 & 0.39 & 0.01 & 0.10 & 0.05 & 0.07 \\
2008 & 0.06 & 0.04 & 0.38 & 0.01 & 0.09 & 0.04 & 0.04 \\
2009 & 0.06 & 0.05 & 0.38 & 0.01 & 0.09 & 0.04 & 0.04 \\
2010 & 0.06 & 0.05 & 0.40 & 0.03 & 0.09 & 0.04 & 0.04 \\
2011 & 0.07 & 0.05 & 0.42 & 0.01 & 0.09 & 0.06 & 0.05 \\
2012 & 0.07 & 0.05 & 0.42 & 0.01 & 0.09 & 0.06 & 0.05 \\
2013 & 0.07 & 0.05 & 0.41 & 0.01 & 0.08 & 0.06 & 0.05 \\
2014 & 0.07 & 0.05 & 0.42 & 0.01 & 0.09 & 0.06 & 0.05 \\
2015 & 0.08 & 0.06 & 0.42 & 0.01 & 0.09 & 0.06 & 0.06 \\
2016 & 0.07 & 0.06 & 0.42 & 0.01 & 0.09 & 0.06 & 0.05 \\
2017 & 0.07 & 0.06 & 0.41 & 0.01 & 0.09 & 0.06 & 0.05 \\
2018 & 0.07 & 0.06 & 0.40 & 0.01 & 0.08 & 0.06 & 0.05 \\
2019 & 0.07 & 0.06 & 0.40 & 0.01 & 0.09 & 0.06 & 0.05 \\
\hline
\end{tabular}

Table 9. $\beta$-Convergence of the supply in each tourist destination. Source: compiled by the authors.

\begin{tabular}{cccc}
\hline Region & $\Omega$ & $\beta$-Convergence & $\mathbf{R}^{2}$ \\
\hline Andalusia & -0.32 & -0.07 & 0.07 \\
Balearic Islands & $-0.15^{* * *}$ & $-0.18^{* * *}$ & 0.45 \\
Canary Islands & $-5.17^{* * *}$ & $-1.09^{* * *}$ & 0.58 \\
Catalonia & -0.19 & -0.10 & 0.13 \\
Valencian Community & -0.59 & -0.21 & 0.12 \\
Murcia Region & -0.88 & -0.33 & 0.14 \\
\hline
\end{tabular}

Note: ${ }^{* * *}$ probabilistically significant at $90 \%$.

In addition to the indicator supply, that of hotel establishments that are open, other indicators have been analysed and have been grouped into the following three categories:

- Administration of supply: number of available places and contracted personnel.

- Adaptation of supply to demand: degree of occupancy of available places.

- Profitability: average hotel rate and income per available room.

The indicators related to administration of supply generally show seasonality, except for the Canary Islands. When comparing the results of Table 8 with those of Table A5 of Appendix B, it can be concluded that, in general, the establishments remain open despite the drop in demand. However, the seasonality of the demand leads to adaptation of the resources used, such as the vacancies and the personnel hired.

Likewise, analysis of the indicator which measures the adequacy between supply and demand, that of the degree of occupancy of the rooms offered in the hotel establishments, shows seasonal behaviour, which indicates that although the hotels remain open, the degree of occupancy of these is determined, as expected, by the demand (see Table A6 of Appendix B).

Finally, in relation to the seasonality of the indicators of profitability, it is observed that Andalusia, the Balearic Islands, and the Valencian Community present certain seasonality in their average rates (see Table A7 of Appendix B). For the other tourist destinations, this indicator shows no presence of seasonality. The indicator of income per available room presents, except in the Canary Islands, seasonality in all tourist destinations, and to a 
greater extent in Andalusia, the Balearic Islands, and the Valencian Community. Clearly, income per room is affected by the seasonal behaviour of tourist demand.

\subsection{Econometric Model}

As indicated in the previous section, two econometric models are specified that attempt to contrast whether the Imserso Social Tourism Programme has contributed to a reduction of seasonality in tourism activity in Spain.

From the point of view of demand, the objective variable used is that of the seasonal intensity of the number of total travellers in hotel establishments. The degree or intensity of seasonality of each of the tourist destinations is measured through the natural logarithm of the six proposed seasonality coefficients.

The results of the estimations of the econometric models of demand, through Equation (11), are disparate (see Table 10). When the VC, GC and WLC coefficients are used as seasonality indices, the results suggest that the seasonality of all types of travellers staying in hotel establishments shows a high inertia and, in addition, the number of travellers using the Imserso programme in periods of low demand and the price of trips financed by Imserso are probabilistically significant.

Table 10. Results of the econometric model of demand (indicator: number of total travellers in hotel establishments). Source: compiled by the authors based on the estimation of Equation (11).

\begin{tabular}{|c|c|c|c|c|c|c|}
\hline $\begin{array}{l}\text { Variables of the } \\
\text { Econometric Model }\end{array}$ & (a) & (b) & (c) & (d) & (e) & (f) \\
\hline Endogenous $_{d t} \rightarrow$ & $\log \left(V C_{d t}\right)$ & $\log \left(E C_{d t}\right)$ & $\log \left(G C_{d t}\right)$ & $\log \left(M C_{d t}\right)$ & $\log \left(O C_{d t}\right)$ & $\log \left(W L C_{d t}\right)$ \\
\hline Endogenous $_{d t-1}$ & $0.70^{* * *}$ & $0.87^{* * *}$ & $0.67^{* * *}$ & $0.23^{* * *}$ & $0.79^{* * *}$ & $0.62^{* * *}$ \\
\hline $\log \left(V_{I M S d t}\right)^{-1}$ & $-0.07^{* * *}$ & -0.00 & $-0.07^{* * *}$ & 0.06 & -0.00 & $-0.07^{* *}$ \\
\hline $\log \left(V_{I M S} d t-1\right)$ & 0.01 & 0.00 & 0.01 & $-0.11^{* *}$ & 0.00 & 0.01 \\
\hline $\log \left(P_{I M S d t}\right)$ & $0.10^{* * *}$ & -0.00 & $0.11^{* * *}$ & 0.12 & 0.01 & $0.09^{* * *}$ \\
\hline $\log \left(P_{I M S d t-1}\right)$ & 0.02 & 0.00 & 0.01 & 0.09 & -0.00 & 0.03 \\
\hline Dummies time & Yes & Yes & Yes & Yes & Yes & Yes \\
\hline$D_{T U R}$ & Yes & Yes & Yes & Yes & Yes & Yes \\
\hline R-squared & 0.99 & 0.99 & 0.99 & 0.98 & 0.99 & 0.99 \\
\hline Adjusted R-sq & 0.99 & 0.99 & 0.99 & 0.98 & 0.99 & 0.99 \\
\hline AIC & -2.50 & -8.53 & -2.33 & -0.99 & -6.50 & -2.15 \\
\hline Observations & 114 & 114 & 114 & 114 & 114 & 114 \\
\hline
\end{tabular}

Note $1:{ }^{* *}$ and ${ }^{* * *}$ probabilistically significant at $95 \%$ and $90 \%$, respectively. Note 2 : VC is variation coefficient, EC is entropy, GC is Gini; MC is Markham, OC is Oliver; WLC is Walsh-Lawler.

The number of travellers using the Imserso programme therefore contributes to a decrease in the behaviour of seasonality. However, the price of the trips subsidised by Imserso have a positive influence on seasonality, indicating that a decrease in the value of the subsidy does not translate into a fall in demand and therefore an increase in seasonality, as might be expected, but rather it decreases the seasonality of tourist destinations. The explanation for this sign and the reduction in seasonality lies in the fact that the demand from the beneficiaries of the programme is inelastic and so, despite the decrease in the value of the subsidy, the demand for travel remains high and the beneficiaries are prepared to pay more for their holidays.

Since the objective variable in the different specifications is different, the results of the different estimates cannot be directly compared (see Table 10). In the estimates of Equations (a), (c) and (f) the negative sign of the coefficient of the variable number of travellers subsidised by the Imserso programme is statistically significant, with a probability of $99 \%$, which indicates that the higher the number of travellers, the greater would be the decrease in tourist seasonality. With respect to the price of the trips subsidised by Imserso, its regression coefficient is statistically significant and with a positive sign, as was seen with the Gini coefficient. 
The results obtained in the estimation of the econometric models (see Table 10) confirm the existence of seasonality in the demand, as indicated by the different statistics (adjusted $\mathrm{R}$ squared). Additionally, we note that the diversity of results, in terms of explanatory variables, is justified by the fact that the six seasonality coefficients used characterize seasonality from different points of view, so that while some are more sensitive to asymmetry, others may be to kurtosis (in a future work, it could be interesting to use a Montecarlo simulation to quantify (synthetically) the impact on the indicators of seasonality and, subsequently, on the measure of seasonality (symmetry, kurtosis or dispersivity...).

Since 2012, the value of the subsidy offered by Imserso has been steadily decreasing while the demand from potential beneficiaries has not, and so the reduction in seasonality has been maintained (see Appendix A). Lastly, it should be noted that the elasticity, in absolute values, is slightly higher for prices than for the number of travellers subsidised by Imserso.

The results of the estimations of the econometric models of supply (see Table 11), using the number of hotel establishments that are open, show a high inertia, meaning that the price of the trips subsidised by Imserso and the number of travellers benefitting from the programme in periods of low tourist demand do not influence the seasonality of the supply, since they are not statistically significant, with a probability of $95 \%$. Therefore, neither the value of the subsidy nor the number of subsidised trips affects the seasonality of the tourist activity. The reason for this is because the supply does not really respond to the value of the subsidy or to the number of places that Imserso assigns in each programme.

Table 11. Results of econometric model of supply (indicator: number of hotel establishments that are open). Source: compiled by the authors based on the estimation of Equation (12).

\begin{tabular}{|c|c|c|c|c|c|c|}
\hline $\begin{array}{c}\text { Variables of the } \\
\text { Econometric Model }\end{array}$ & (a) & (b) & (c) & (d) & (e) & (f) \\
\hline Endogenous $_{d t} \rightarrow$ & $\log \left(V C_{d t}\right)$ & $\log \left(E C_{d t}\right)$ & $\log \left(G C_{d t}\right)$ & $\log \left(M C_{d t}\right)$ & $\log \left(O C_{d t}\right)$ & $\log \left(W L C_{d t}\right)$ \\
\hline Endogena $_{d t-1}$ & $0.41^{* * *}$ & $0.46^{* * *}$ & $0.41^{* * *}$ & $0.44^{* * *}$ & $0.47^{* * *}$ & $0.41^{* * *}$ \\
\hline $\log \left(V_{I M S} d t\right)$ & 0.36 & -0.01 & -0.41 & -0.68 & 0.03 & -0.45 \\
\hline $\log \left(V_{I M S} d t-1\right)$ & -0.22 & 0.01 & -0.19 & 0.11 & -0.03 & -0.17 \\
\hline $\log \left(P_{I M S d t}\right)$ & -0.21 & -0.01 & 0.21 & 0.40 & 0.05 & 0.22 \\
\hline $\log \left(P_{I M S d t-1}\right)$ & 0.21 & -0.02 & 0.22 & 0.17 & -0.07 & 0.21 \\
\hline Dummies time & Yes & Yes & Yes & Yes & Yes & Yes \\
\hline$D_{T U R}$ & Yes & Yes & Yes & Yes & Yes & Yes \\
\hline R-squared & 0.23 & 0.41 & 0.23 & 0.25 & 0.42 & 0.23 \\
\hline Adjusted R-sq & 0.14 & 0.34 & 0.15 & 0.17 & 0.35 & 0.15 \\
\hline AIC & 3.22 & -3.68 & 3.23 & 3.19 & -1.38 & 3.30 \\
\hline Observations & 114 & 114 & 114 & 114 & 114 & 114 \\
\hline
\end{tabular}

Note 1: *** probabilistically significant at $90 \%$. Note 2 : VC is variation coefficient, EC is entropy, GC is Gini; MC is Markham, OC is Oliver; WLC is Walsh-Lawler.

The scarce seasonality in the supply is due to the fact that tourist agents themselves, to the extent of their possibilities, adapt the offer to the existing demand in periods of low tourism activity. In this way, tourism entrepreneurs, in general, keep their establishments open and adapt their offer to demand by modifying the degree of occupancy and the personnel hired. Only in the Balearic Islands, where the level of foreign tourism is high, does supply present high seasonality as well as demand.

\section{Conclusions}

The contribution of this paper is to quantify the seasonality of tourism activity, both in terms of supply and demand and, on the other hand, to analyse and quantify the impact of programmes for the elderly in Spain to see whether this type of program helps to alleviate the seasonality of tourism activity. The results indicate that seasonality in the tourism sector is an inherent characteristic present, to a greater or lesser extent, in many of the 
member countries of the EU, although it is evident that in countries where tourism activity is more significant, the intensity of seasonality is higher; seasonality in the tourism sector is an inherent characteristic present, to a greater or lesser extent, in many of the member countries of the EU, although it is evident that in countries where tourism activity is more significant, the intensity of seasonality is higher.

Seasonality in tourism activity in Spain is a greater problem than in the EU as a whole and has been increasing year on year. In some Spanish tourist destinations, such as the Balearic Islands, the situation is particularly acute, especially in the segment of foreign tourists visiting the islands.

The results of the econometric models suggest that the Imserso Social Tourism Programme is effective in reducing the seasonality of tourism activity in Spain from the perspective of demand. However, further improvement could be made by increasing the number of places made available, since the number of applications tends to be triple the number of places on offer. Similarly, the value of the subsidy offered by the Imserso programme has almost halved from the beginning of the period under study to the present, while the spending by Imserso users has increased by $60 \%$, with no reduction in applications to the programme. This suggests that more places could be offered and, although this would require an increase in the budget of the programme, given the economic and social benefits derived from the programme, its expansion and further development merits consideration.

Companies should also instigate campaigns to attract retired people and/or people with free time to travel outside of the high season. Even if the trips are not subsidised by Imserso, a good marketing campaign, with attractive and competitive prices, would attract the attention and interest of the target public.

Local authorities could promote other types of tourism, different from the seasondriven beach and sun holidays, such as congress and/or urban tourism. These alternatives would require, among other things, large venues for conferences, an interesting offer of museums and an adequate public transport system, as well as infrastructures that administrations must ensure are adapted to meet specific needs.

Another possible way to reduce seasonality could be achieved through price discrimination in hotel establishments in periods of low demand, in order to increase demand. Hotel rates do not present, in general, a high seasonality. If prices were better adapted to demand, that is, if they were reduced in periods of low demand, they could potentially attract more tourists.

Author Contributions: Conceptualization, B.C.-B. and F.M.-J.; data curation, F.M.-J.; formal analysis, P.R., B.C.-B. and F.M.-J.; investigation, P.R., B.C.-B. and F.M.-J.; methodology, P.R., B.C.-B. and F.M.-J.; software, F.M.-J.; writing—original draft, P.R. and F.M.-J.; writing—review and editing, P.R., B.C.-B. and F.M.-J. All authors have read and agreed to the published version of the manuscript.

Funding: This research received no external funding.

Informed Consent Statement: Not applicable.

Data Availability Statement: Eurostat (https:/ / ec.europa.eu/eurostat/data/database accessed on 26 July 2021) and INE, Instituto Nacional de Estadística de España (https://ine.es accessed on 26 July 2021).

Conflicts of Interest: The authors declare no conflict of interest.

\section{Appendix A}

The Imserso Programme

The management and provision of the services necessary to run the programme are organised and partially financed by the Ministry of Labour and Social Affairs by way of open tender via Imserso with companies in the tourism sector. The programme is run from October of one year to June of the next, with four possible modalities: beach holidays, cultural trips, rural tourism and exchanges with other countries. 
The programme is offered as a package that includes the cost of the round trip in whatever mode of transport is stipulated, accommodation with full board, a collective travel insurance policy, health care supplementary to Social Security and the offer of free leisure activities.

From its inception to the present time, the Social Tourism Programme has undergone various modifications, such as in the 1990/91 season with the inclusion of Spanish citizens residing in European countries; in 1993/94, this was also extended to Spanish residents in other foreign countries. In the 1997/98 season, and until 2012, through a collaboration agreement with Portugal, Spanish citizens were able to enjoy organised trips to towns in Portugal, and a reciprocal number of Portuguese visitors could enjoy the trips on offer in Spain.

In the 2000/01 and 2001/02 seasons, which correspond to the beginning of the period under study in this paper, a total of 400,000 places were offered, of which around $98-99 \%$ were taken up. The number of applications was double the number of places offered. Over the years that followed, the number of places gradually increased, reaching $1,200,000$ in the 2008/09 and 2009/10 seasons, but since then the places offered have been reducing, dropping to 938,000 in the $2018 / 19$ season while the number of people applying has risen to $3,993,540$.

In the $2018 / 19$ season, Imserso contributed to $20.73 \%$ of the total cost of the trip. However, the contribution made by Imserso, which increased continuously until 2010, has since been decreasing until reaching levels that are $40 \%$ lower in recent years compared to the level reached in 2010. In contrast, the contribution paid by participants in the programme has increased, and yet the number of applications has not dropped. In fact, the figures show quite the opposite, with the number of applications continuing to increase. This suggests that there is a strong argument for increasing the number of places available, although this would require an increase in the programme's budget. However, given its social and economic benefits, such an improvement is worth considering.

The programme has a not insignificant effect on the economy. For example, in the 2018-2019 season, 12,473 direct jobs and 73,461 total jobs were generated. This generated employment has an overall positive impact on the economy and, in particular, on the state coffers through Social Security contributions, personal income tax, VAT and other taxes and savings in unemployment benefits.

In addition to the Social Tourism Programme, the Active Ageing Programme also includes the Thermalism Programme. This programme began in 1989 as a social services policy to satisfy the demand of the elderly to be able to receive recuperative treatments in specialised thermal establishments.

This programme has a two-fold objective:

(1) To facilitate the access of pensioners of the Social Security System to treatments in spas provided for people of this group, who need it by medical prescription, in order that the thermal treatment can act in a preventive and curative way or as rehabilitation of chronic diseases and disabling diseases, thus helping to improve their quality of life and at a reduced price thanks to the co-financing of the Imserso.

(2) To promote the economic development of the areas in which the spas are located, contributing to the creation and maintenance of employment, facilitating the improvement and modernisation of the infrastructures and facilities of these centres and allowing professionalisation and specialisation of the staff who provide their services in these establishments.

Over the 2000/01 season, 80,000 places were offered by the programme, with this systematically increasing until the 2011/12 season, after which the places offered dropped to 208,500 places in the last two seasons of the period considered. However, both the applications received and the number of beneficiaries increased continuously until the 2011/12 season, after which they decreased. In the 2018/19 season, 274,844 people applied for the thermalism programme, of which 184,440 people were allocated a place. The percentage of beneficiaries compared to available places stood at $88.5 \%$ in the $2011 / 12$ season, 
meaning that more than $10 \%$ of places remained unfilled. The reason for this is not clearly explained by Imserso, but if it were due to management of the programme then this could be improved, with the subsequent social and economic repercussions that would ensue. Imserso's contribution to this programme was increasing until the 2012 and 2013 seasons, when funds were substantially cut, to recover again in 2014. In recent years, Imserso's contribution has remained stable.

Finally, it should be noted that the satisfaction of the users of both programmes is very high, with more than $95 \%$ of the users of the social tourism programme and around $90 \%$ of the users of the thermalism programme stating that they were very satisfied or satisfied.

\section{Appendix B}

Table A1. Gini coefficient of national travellers in hotel establishments in EU countries.

\begin{tabular}{cccccccccc}
\hline Year & Germany & Austria & Spain & France & Holland & Italy & Portugal & UK & Sweden \\
\hline 1999 & 0.13 & 0.12 & 0.16 & n.a. & 0.19 & 0.20 & 0.17 & 0.22 & 0.10 \\
2000 & 0.13 & 0.12 & 0.16 & n.a. & 0.17 & 0.20 & 0.18 & 0.17 & 0.11 \\
2001 & 0.13 & 0.11 & 0.17 & n.a. & 0.18 & 0.19 & 0.17 & 0.18 & 0.20 \\
2002 & 0.13 & 0.11 & 0.16 & n.a. & 0.18 & 0.20 & 0.17 & 0.14 & 0.20 \\
2003 & 0.15 & 0.12 & 0.18 & n.a. & 0.19 & 0.20 & 0.18 & 0.16 & 0.22 \\
2004 & 0.12 & 0.11 & 0.17 & n.a. & 0.17 & 0.19 & 0.17 & 0.14 & 0.25 \\
2005 & 0.12 & 0.10 & 0.17 & n.a. & 0.17 & 0.19 & 0.17 & 0.18 & 0.27 \\
2006 & 0.12 & 0.10 & 0.16 & n.a. & 0.16 & 0.19 & 0.17 & 0.18 & 0.22 \\
2007 & 0.12 & 0.10 & 0.15 & n.a. & 0.14 & 0.19 & 0.16 & 0.18 & 0.23 \\
2008 & 0.12 & 0.10 & 0.15 & n.a. & 0.14 & 0.19 & 0.16 & 0.18 & 0.20 \\
2009 & 0.13 & 0.10 & 0.17 & n.a. & 0.15 & 0.20 & 0.17 & 0.20 & 0.21 \\
2010 & 0.13 & 0.10 & 0.17 & n.a. & 0.16 & 0.20 & 0.16 & 0.19 & 0.20 \\
2011 & 0.13 & 0.10 & 0.18 & 0.17 & 0.14 & 0.20 & 0.18 & 0.18 & 0.20 \\
2012 & 0.12 & 0.10 & 0.17 & 0.16 & 0.15 & 0.20 & 0.19 & 0.18 & 0.19 \\
2013 & 0.13 & 0.10 & 0.18 & 0.17 & 0.17 & 0.20 & 0.20 & 0.19 & 0.20 \\
2014 & 0.12 & 0.10 & 0.18 & 0.17 & 0.16 & 0.20 & 0.19 & 0.21 & 0.20 \\
2015 & 0.13 & 0.11 & 0.17 & 0.18 & 0.16 & 0.21 & 0.18 & 0.18 & 0.19 \\
2016 & 0.12 & 0.11 & 0.17 & 0.17 & 0.15 & 0.20 & 0.17 & 0.18 & 0.20 \\
2017 & 0.12 & 0.11 & 0.17 & 0.17 & 0.13 & 0.20 & 0.17 & 0.19 & 0.18 \\
2018 & 0.12 & 0.10 & 0.16 & 0.16 & 0.13 & 0.19 & 0.16 & 0.18 & 0.17 \\
2019 & 0.12 & 0.11 & 0.17 & 0.18 & 0.13 & 0.19 & 0.16 & 0.20 & 0.19 \\
\hline
\end{tabular}

Source: compiled by the authors using data from Eurostat.

Table A2. Gini coefficient of foreign travellers in hotel establishments in EU countries.

\begin{tabular}{cccccccccc}
\hline Year & Germany & Austria & Spain & France & Holland & Italy & Portugal & UK & Sweden \\
\hline 1999 & 0.17 & 0.12 & 0.23 & n.a. & 0.17 & 0.25 & 0.21 & 0.20 & 0.27 \\
2000 & 0.18 & 0.12 & 0.20 & n.a. & 0.17 & 0.27 & 0.21 & 0.20 & 0.26 \\
2001 & 0.16 & 0.11 & 0.21 & n.a. & 0.16 & 0.27 & 0.20 & 0.19 & 0.36 \\
2002 & 0.16 & 0.11 & 0.21 & n.a. & 0.17 & 0.26 & 0.21 & 0.21 & 0.37 \\
2003 & 0.15 & 0.12 & 0.21 & n.a. & 0.17 & 0.25 & 0.21 & 0.16 & 0.37 \\
2004 & 0.15 & 0.11 & 0.21 & n.a. & 0.15 & 0.24 & 0.21 & 0.17 & 0.41 \\
2005 & 0.15 & 0.10 & 0.21 & n.a. & 0.13 & 0.25 & 0.20 & 0.16 & 0.40 \\
2006 & 0.15 & 0.10 & 0.21 & n.a. & 0.15 & 0.25 & 0.21 & 0.17 & 0.37 \\
2007 & 0.14 & 0.10 & 0.20 & n.a. & 0.12 & 0.25 & 0.21 & 0.15 & 0.40 \\
2008 & 0.14 & 0.10 & 0.20 & n.a. & 0.12 & 0.25 & 0.20 & 0.16 & 0.34 \\
2009 & 0.15 & 0.10 & 0.21 & n.a. & 0.14 & 0.26 & 0.21 & 0.16 & 0.34 \\
2010 & 0.16 & 0.10 & 0.22 & n.a. & 0.14 & 0.27 & 0.22 & 0.19 & 0.35 \\
2011 & 0.15 & 0.10 & 0.22 & 0.29 & 0.15 & 0.26 & 0.24 & 0.18 & 0.34 \\
2012 & 0.14 & 0.10 & 0.23 & 0.28 & 0.14 & 0.27 & 0.23 & 0.16 & 0.33 \\
2013 & 0.14 & 0.10 & 0.23 & 0.28 & 0.15 & 0.28 & 0.23 & 0.19 & 0.31 \\
2014 & 0.14 & 0.10 & 0.22 & 0.28 & 0.15 & 0.28 & 0.23 & 0.18 & 0.32 \\
\hline
\end{tabular}


Table A2. Cont.

\begin{tabular}{cccccccccc}
\hline Year & Germany & Austria & Spain & France & Holland & Italy & Portugal & UK & Sweden \\
\hline 2015 & 0.15 & 0.11 & 0.22 & 0.29 & 0.15 & 0.28 & 0.22 & 0.19 & 0.31 \\
2016 & 0.13 & 0.11 & 0.22 & 0.27 & 0.13 & 0.28 & 0.21 & 0.16 & 0.32 \\
2017 & 0.13 & 0.11 & 0.21 & 0.26 & 0.14 & 0.28 & 0.21 & 0.16 & 0.31 \\
2018 & 0.13 & 0.10 & 0.20 & 0.25 & 0.13 & 0.27 & 0.19 & 0.15 & 0.29 \\
2019 & 0.13 & 0.11 & 0.20 & 0.25 & 0.14 & 0.27 & 0.19 & 0.16 & 0.31 \\
\hline
\end{tabular}

Source: compiled by the authors using data from Eurostat.

Table A3. Gini coefficient of national travellers in hotel establishments by tourist destination in Spain.

\begin{tabular}{cccccccc}
\hline Year & Spain & Andalusia & $\begin{array}{c}\text { Balearic } \\
\text { Islands }\end{array}$ & $\begin{array}{c}\text { Canary } \\
\text { Islands }\end{array}$ & Catalonia & $\begin{array}{c}\text { Valencian } \\
\text { Community }\end{array}$ & $\begin{array}{c}\text { Murcia } \\
\text { Region }\end{array}$ \\
\hline 2001 & 0.11 & 0.11 & 0.20 & 0.13 & 0.12 & 0.14 & 0.10 \\
2002 & 0.11 & 0.11 & 0.22 & 0.14 & 0.11 & 0.14 & 0.10 \\
2003 & 0.13 & 0.12 & 0.26 & 0.17 & 0.14 & 0.15 & 0.09 \\
2004 & 0.13 & 0.11 & 0.30 & 0.18 & 0.14 & 0.14 & 0.08 \\
2005 & 0.13 & 0.11 & 0.31 & 0.17 & 0.15 & 0.13 & 0.09 \\
2006 & 0.12 & 0.12 & 0.29 & 0.17 & 0.15 & 0.13 & 0.10 \\
2007 & 0.12 & 0.13 & 0.31 & 0.17 & 0.14 & 0.14 & 0.09 \\
2008 & 0.12 & 0.14 & 0.31 & 0.17 & 0.13 & 0.14 & 0.10 \\
2009 & 0.13 & 0.15 & 0.31 & 0.17 & 0.15 & 0.15 & 0.12 \\
2010 & 0.13 & 0.16 & 0.33 & 0.15 & 0.14 & 0.15 & 0.11 \\
2011 & 0.14 & 0.15 & 0.32 & 0.16 & 0.15 & 0.17 & 0.12 \\
2012 & 0.13 & 0.16 & 0.30 & 0.16 & 0.13 & 0.17 & 0.11 \\
2013 & 0.14 & 0.17 & 0.30 & 0.16 & 0.14 & 0.17 & 0.13 \\
2014 & 0.14 & 0.17 & 0.33 & 0.18 & 0.14 & 0.17 & 0.11 \\
2015 & 0.14 & 0.15 & 0.33 & 0.18 & 0.16 & 0.17 & 0.11 \\
2016 & 0.13 & 0.14 & 0.31 & 0.16 & 0.16 & 0.16 & 0.10 \\
2017 & 0.13 & 0.13 & 0.31 & 0.17 & 0.16 & 0.15 & 0.10 \\
2018 & 0.12 & 0.13 & 0.29 & 0.17 & 0.15 & 0.15 & 0.09 \\
2019 & 0.13 & 0.15 & 0.33 & 0.18 & 0.15 & 0.15 & 0.10 \\
\hline
\end{tabular}

Source: compiled by the authors using data from INE.

Table A4. Gini coefficient of foreign travellers in hotel establishments by tourist destination in Spain.

\begin{tabular}{cccccccc}
\hline Year & Spain & Andalusia & $\begin{array}{c}\text { Balearic } \\
\text { Islands }\end{array}$ & $\begin{array}{c}\text { Canary } \\
\text { Islands }\end{array}$ & Catalonia & $\begin{array}{c}\text { Valencian } \\
\text { Community }\end{array}$ & $\begin{array}{c}\text { Murcia } \\
\text { Region }\end{array}$ \\
\hline 2001 & 0.20 & 0.18 & 0.40 & 0.05 & 0.27 & 0.09 & 0.10 \\
2002 & 0.20 & 0.18 & 0.42 & 0.08 & 0.26 & 0.10 & 0.14 \\
2003 & 0.20 & 0.18 & 0.44 & 0.06 & 0.24 & 0.12 & 0.10 \\
2004 & 0.20 & 0.17 & 0.45 & 0.07 & 0.23 & 0.10 & 0.09 \\
2005 & 0.20 & 0.17 & 0.45 & 0.07 & 0.24 & 0.11 & 0.09 \\
2006 & 0.20 & 0.18 & 0.44 & 0.04 & 0.24 & 0.10 & 0.07 \\
2007 & 0.19 & 0.17 & 0.45 & 0.07 & 0.23 & 0.11 & 0.12 \\
2008 & 0.20 & 0.18 & 0.45 & 0.06 & 0.23 & 0.14 & 0.13 \\
2009 & 0.20 & 0.19 & 0.45 & 0.06 & 0.23 & 0.14 & 0.12 \\
2010 & 0.21 & 0.20 & 0.47 & 0.07 & 0.23 & 0.15 & 0.12 \\
2011 & 0.22 & 0.20 & 0.48 & 0.06 & 0.24 & 0.17 & 0.11 \\
2012 & 0.22 & 0.20 & 0.49 & 0.05 & 0.24 & 0.17 & 0.13 \\
2013 & 0.22 & 0.20 & 0.48 & 0.06 & 0.25 & 0.17 & 0.14 \\
2014 & 0.22 & 0.20 & 0.49 & 0.05 & 0.24 & 0.16 & 0.15 \\
2015 & 0.21 & 0.20 & 0.48 & 0.05 & 0.23 & 0.16 & 0.16 \\
2016 & 0.21 & 0.19 & 0.48 & 0.04 & 0.22 & 0.15 & 0.14 \\
2017 & 0.20 & 0.18 & 0.47 & 0.03 & 0.22 & 0.15 & 0.16 \\
2018 & 0.19 & 0.17 & 0.47 & 0.03 & 0.20 & 0.13 & 0.14 \\
2019 & 0.19 & 0.17 & 0.46 & 0.04 & 0.20 & 0.13 & 0.15 \\
\hline
\end{tabular}

Source: compiled by the authors using data from INE. 
Table A5. Seasonality in tourism management by tourist destination. Gini coefficient of the number of places available.

\begin{tabular}{cccccccc}
\hline Year & Spain & Andalusia & $\begin{array}{c}\text { Balearic } \\
\text { Islands }\end{array}$ & $\begin{array}{c}\text { Canary } \\
\text { Islands }\end{array}$ & Catalonia & $\begin{array}{c}\text { Valencian } \\
\text { Community }\end{array}$ & $\begin{array}{c}\text { Murcia } \\
\text { Region }\end{array}$ \\
\hline 2001 & 0.12 & 0.05 & 0.34 & 0.00 & 0.21 & 0.07 & 0.07 \\
2002 & 0.12 & 0.06 & 0.36 & 0.01 & 0.20 & 0.07 & 0.06 \\
2003 & 0.12 & 0.06 & 0.38 & 0.01 & 0.21 & 0.07 & 0.05 \\
2004 & 0.12 & 0.06 & 0.38 & 0.01 & 0.20 & 0.06 & 0.05 \\
2005 & 0.11 & 0.06 & 0.38 & 0.01 & 0.19 & 0.05 & 0.06 \\
2006 & 0.11 & 0.07 & 0.38 & 0.02 & 0.19 & 0.05 & 0.07 \\
2007 & 0.11 & 0.06 & 0.39 & 0.01 & 0.18 & 0.05 & 0.06 \\
2008 & 0.11 & 0.06 & 0.39 & 0.01 & 0.17 & 0.04 & 0.07 \\
2009 & 0.11 & 0.07 & 0.41 & 0.01 & 0.17 & 0.05 & 0.07 \\
2010 & 0.11 & 0.08 & 0.42 & 0.03 & 0.16 & 0.05 & 0.07 \\
2011 & 0.11 & 0.08 & 0.42 & 0.01 & 0.16 & 0.06 & 0.07 \\
2012 & 0.11 & 0.09 & 0.43 & 0.01 & 0.16 & 0.07 & 0.07 \\
2013 & 0.12 & 0.11 & 0.44 & 0.01 & 0.16 & 0.07 & 0.08 \\
2014 & 0.12 & 0.11 & 0.45 & 0.00 & 0.16 & 0.07 & 0.07 \\
2015 & 0.12 & 0.11 & 0.45 & 0.01 & 0.16 & 0.07 & 0.07 \\
2016 & 0.12 & 0.11 & 0.44 & 0.01 & 0.16 & 0.07 & 0.07 \\
2017 & 0.12 & 0.11 & 0.44 & 0.01 & 0.16 & 0.07 & 0.08 \\
2018 & 0.12 & 0.11 & 0.44 & 0.01 & 0.16 & 0.07 & 0.08 \\
2019 & 0.12 & 0.11 & 0.44 & 0.01 & 0.16 & 0.07 & 0.08 \\
\hline
\end{tabular}

\begin{tabular}{cccccccc}
\multicolumn{7}{c}{ Gini Coefficient of Hired Personnel } & \\
\hline Year & Spain & Andalusia & $\begin{array}{c}\text { Balearic } \\
\text { Islands }\end{array}$ & $\begin{array}{c}\text { Canary } \\
\text { Islands }\end{array}$ & Catalonia & $\begin{array}{c}\text { Valencian } \\
\text { Commu- } \\
\text { nity }\end{array}$ & $\begin{array}{c}\text { Murcia } \\
\text { Region }\end{array}$ \\
\hline 2002 & 0.12 & 0.07 & 0.36 & 0.01 & 0.20 & 0.12 & 0.08 \\
2003 & 0.12 & 0.08 & 0.37 & 0.01 & 0.20 & 0.09 & 0.07 \\
2004 & 0.13 & 0.09 & 0.39 & 0.01 & 0.20 & 0.10 & 0.06 \\
2005 & 0.12 & 0.08 & 0.38 & 0.01 & 0.18 & 0.08 & 0.07 \\
2006 & 0.12 & 0.11 & 0.38 & 0.02 & 0.17 & 0.07 & 0.08 \\
2007 & 0.12 & 0.11 & 0.39 & 0.03 & 0.16 & 0.08 & 0.08 \\
2008 & 0.11 & 0.10 & 0.39 & 0.01 & 0.16 & 0.07 & 0.09 \\
2009 & 0.11 & 0.10 & 0.40 & 0.01 & 0.15 & 0.07 & 0.08 \\
2010 & 0.11 & 0.11 & 0.42 & 0.01 & 0.15 & 0.08 & 0.08 \\
2011 & 0.12 & 0.12 & 0.43 & 0.03 & 0.15 & 0.09 & 0.09 \\
2012 & 0.12 & 0.13 & 0.44 & 0.01 & 0.15 & 0.10 & 0.08 \\
2013 & 0.13 & 0.14 & 0.45 & 0.01 & 0.15 & 0.11 & 0.09 \\
2014 & 0.13 & 0.15 & 0.46 & 0.02 & 0.15 & 0.11 & 0.11 \\
2015 & 0.14 & 0.16 & 0.47 & 0.01 & 0.16 & 0.11 & 0.11 \\
2016 & 0.14 & 0.15 & 0.47 & 0.02 & 0.15 & 0.11 & 0.10 \\
2017 & 0.14 & 0.15 & 0.46 & 0.02 & 0.16 & 0.12 & 0.10 \\
2018 & 0.14 & 0.16 & 0.46 & 0.01 & 0.16 & 0.11 & 0.10 \\
2019 & 0.14 & 0.16 & 0.45 & 0.02 & 0.15 & 0.10 & 0.08 \\
\hline S0urce: & & & & & & & \\
\hline
\end{tabular}

Source: compiled by the authors using data from INE.

Table A6. Seasonality in the adaptation of the offer to the tourist demand. Gini coefficient of the degree of occupancy by tourist destination.

\begin{tabular}{cccccccc}
\hline Year & Spain & Andalusia & $\begin{array}{c}\text { Balearic } \\
\text { Islands }\end{array}$ & $\begin{array}{c}\text { Canary } \\
\text { Islands }\end{array}$ & Catalonia & $\begin{array}{c}\text { Valencian } \\
\text { Community }\end{array}$ & $\begin{array}{c}\text { Murcia } \\
\text { Region }\end{array}$ \\
\hline 2001 & 0.12 & 0.14 & 0.14 & 0.04 & 0.15 & 0.08 & 0.11 \\
2002 & 0.11 & 0.14 & 0.16 & 0.05 & 0.15 & 0.09 & 0.11 \\
2003 & 0.12 & 0.14 & 0.15 & 0.05 & 0.14 & 0.10 & 0.10 \\
\hline
\end{tabular}


Table A6. Cont.

\begin{tabular}{cccccccc}
\hline Year & Spain & Andalusia & $\begin{array}{c}\text { Balearic } \\
\text { Islands }\end{array}$ & $\begin{array}{c}\text { Canary } \\
\text { Islands }\end{array}$ & Catalonia & $\begin{array}{c}\text { Valencian } \\
\text { Community }\end{array}$ & $\begin{array}{c}\text { Murcia } \\
\text { Region }\end{array}$ \\
\hline 2004 & 0.11 & 0.13 & 0.15 & 0.06 & 0.13 & 0.10 & 0.09 \\
2005 & 0.12 & 0.13 & 0.15 & 0.06 & 0.14 & 0.10 & 0.10 \\
2006 & 0.11 & 0.13 & 0.14 & 0.05 & 0.14 & 0.10 & 0.10 \\
2007 & 0.11 & 0.14 & 0.15 & 0.05 & 0.14 & 0.11 & 0.09 \\
2008 & 0.12 & 0.15 & 0.16 & 0.05 & 0.15 & 0.12 & 0.11 \\
2009 & 0.12 & 0.16 & 0.17 & 0.05 & 0.16 & 0.13 & 0.12 \\
2010 & 0.13 & 0.17 & 0.19 & 0.05 & 0.16 & 0.14 & 0.12 \\
2011 & 0.13 & 0.16 & 0.21 & 0.06 & 0.17 & 0.15 & 0.13 \\
2012 & 0.13 & 0.16 & 0.20 & 0.05 & 0.17 & 0.15 & 0.13 \\
2013 & 0.13 & 0.16 & 0.20 & 0.05 & 0.17 & 0.15 & 0.14 \\
2014 & 0.12 & 0.16 & 0.20 & 0.04 & 0.16 & 0.15 & 0.14 \\
2015 & 0.12 & 0.14 & 0.19 & 0.04 & 0.15 & 0.14 & 0.13 \\
2016 & 0.11 & 0.13 & 0.17 & 0.04 & 0.14 & 0.13 & 0.13 \\
2017 & 0.11 & 0.13 & 0.18 & 0.03 & 0.14 & 013 & 0.11 \\
2018 & 0.10 & 0.12 & 0.18 & 0.04 & 0.12 & 0.11 & 0.10 \\
2019 & 0.10 & 0.12 & 0.19 & 0.03 & 0.12 & 0.11 & 0.10 \\
\hline
\end{tabular}

Source: compiled by the authors using data from INE.

Table A7. Seasonality of profitability by tourist destination. Gini coefficient of income per available room.

\begin{tabular}{cccccccc}
\hline Year & Spain & Andalusia & $\begin{array}{c}\text { Balearic } \\
\text { Islands }\end{array}$ & $\begin{array}{c}\text { Canary } \\
\text { Islands }\end{array}$ & Catalonia & $\begin{array}{c}\text { Valencian } \\
\text { Community }\end{array}$ & $\begin{array}{c}\text { Murcia } \\
\text { Region }\end{array}$ \\
\hline 2008 & 0.11 & 0.21 & 0.20 & 0.06 & 0.10 & 0.19 & 0.14 \\
2009 & 0.11 & 0.23 & 0.18 & 0.07 & 0.11 & 0.21 & 0.13 \\
2010 & 0.12 & 0.24 & 0.21 & 0.07 & 0.12 & 0.21 & 0.14 \\
2011 & 0.13 & 0.24 & 0.26 & 0.07 & 0.14 & 0.22 & 0.15 \\
2012 & 0.14 & 0.24 & 0.26 & 0.06 & 0.15 & 0.22 & 0.17 \\
2013 & 0.14 & 0.24 & 0.26 & 0.07 & 0.16 & 0.23 & 0.18 \\
2014 & 0.14 & 0.24 & 0.27 & 0.06 & 0.16 & 0.23 & 0.17 \\
2015 & 0.14 & 0.23 & 0.27 & 0.06 & 0.15 & 0.23 & 0.17 \\
2016 & 0.14 & 0.23 & 0.27 & 0.05 & 0.14 & 0.23 & 0.18 \\
2017 & 0.14 & 0.22 & 0.26 & 0.04 & 0.16 & 0.23 & 0.15 \\
2018 & 0.13 & 0.21 & 0.25 & 0.05 & 0.13 & 0.21 & 0.14 \\
2019 & 0.13 & 0.21 & 0.26 & 0.04 & 0.13 & 0.21 & 0.16 \\
\hline
\end{tabular}

Gini Coefficient of the Average Hotel Rate

\begin{tabular}{cccccccc}
\hline Year & Spain & Andalusia & $\begin{array}{c}\text { Balearic } \\
\text { Islands }\end{array}$ & $\begin{array}{c}\text { Canary } \\
\text { Islands }\end{array}$ & Catalonia & $\begin{array}{c}\text { Valencian } \\
\text { Community }\end{array}$ & $\begin{array}{c}\text { Murcia } \\
\text { Region }\end{array}$ \\
\hline 2008 & 0.03 & 0.09 & 0.06 & 0.04 & 0.05 & 0.08 & 0.05 \\
2009 & 0.03 & 0.10 & 0.07 & 0.04 & 0.06 & 0.09 & 0.06 \\
2010 & 0.03 & 0.10 & 0.07 & 0.03 & 0.04 & 0.09 & 0.06 \\
2011 & 0.03 & 0.11 & 0.08 & 0.03 & 0.03 & 0.10 & 0.06 \\
2012 & 0.04 & 0.11 & 0.10 & 0.03 & 0.04 & 0.10 & 0.08 \\
2013 & 0.04 & 0.10 & 0.10 & 0.03 & 0.04 & 0.10 & 0.09 \\
2014 & 0.04 & 0.11 & 0.11 & 0.03 & 0.05 & 0.11 & 0.09 \\
2015 & 0.05 & 0.11 & 0.13 & 0.03 & 0.04 & 0.11 & 0.08 \\
2016 & 0.05 & 0.12 & 0.13 & 0.04 & 0.05 & 0.13 & 0.09 \\
2017 & 0.05 & 0.12 & 0.12 & 0.04 & 0.05 & 0.12 & 0.08 \\
2018 & 0.05 & 0.12 & 0.12 & 0.04 & 0.05 & 0.11 & 0.08 \\
2019 & 0.05 & 0.12 & 0.13 & 0.03 & 0.05 & 0.11 & 0.08 \\
\hline
\end{tabular}




\section{References}

1. Lage, H.G.; Milone, P.C. Impactos socioeconómicos globais do turismo. In Turismo: Teoría y Práctica; Lage, H.G., Milone, P.C., Eds.; Atlas: Sào Paulo, Brazil, 2000; pp. 72-91.

2. Butler, R.W. Seasonality in Tourism: Issues and Problems. In Tourism: The State of the Art; Seaton, A.V., Ed.; Wiley: Chichester, UK, 1994; pp. 332-339.

3. Butler, R.W. Seasonality in Tourism: Issues and Implications. In Seasonality in Tourism; Baum, T., Lundtorp, S., Eds.; PergarmonElservier: Oxford, UK, 2001; pp. 5-22.

4. Butler, R.W.; Mao, B. Seasonality in Tourism: Problems and Measurement. In Quality Management in Urban Tourism; Murphy, P., Ed.; Wiley \& Sons: Chichester, UK, 1997; pp. 9-23.

5. López, J.M.; López, L.M. La concentración estacional en las regiones españolas desde una perspectiva de la oferta turística. Rev. Estud. Reg. 2006, 77, 77-104.

6. Manning, R.E.; Powers, L.A. Peak and Off-Peak Use: Redistributing the Outdoor Recreation/Tourism Load. J. Travel Res. 1984, 23, 25-31. [CrossRef]

7. Ashworth, J.; Thomas, B. Patterns of seasonality in employment in tourism in the UK. Appl. Econ. Lett. 1999, 6, 735-739. [CrossRef]

8. Baum, T. Seasonality in Tourism: Understanding the Challenges. Tour. Econ. 1999, 5, 5-8. [CrossRef]

9. Krakover, S. Partitioning seasonal employment in the hospitality industry. Tour. Manag. 2000, 21, 461-471. [CrossRef]

10. Allcock, J. Seasonality. In Tourism Marketing and Management Handbook; Witt, S.F., Motuinho, L., Eds.; Prentice Hall: New York, NY, USA, 1994; pp. 86-92.

11. Lundtorp, S. Measuring Tourism Seasonality. In Seasonality in Tourism; Baum, T., Lundtorp, S., Eds.; Pergamon: Oxford, UK, 2001; pp. 23-50.

12. Baum, T.; Lundtorp, S. Seasonality in Tourism; Pergamon: Oxford, UK, 2001.

13. Greenidge, K. Forecasting tourism demand. An STM Approach. Ann. Tour. Res. 2001, 28, 98-112. [CrossRef]

14. Goh, C.; Law, R. Modeling and forecasting tourism demand for arrivals with stochastic nonstationary seasonality and intervention. Tour. Manag. 2002, 23, 499-510. [CrossRef]

15. Gustafson, P. Tourism and seasonal retirement migration. Ann. Tour. Res. 2002, 29, 899-918. [CrossRef]

16. Jolliffe, L.; Farnsworth, R. Seasonality issues. In Extreme Tourism: Lessons from the World's Cold Water Islands; Baldacchino, G., Ed.; Elsevier: Oxford, UK, 2006; pp. 51-59.

17. Fernández-Morales, A. Decomposing seasonal concentration. Ann. Tour. Res. 2003, 30, 942-956. [CrossRef]

18. Nadal, J.R.; Font, A.R.; Rosselló, J. The economic determinants of seasonal patterns. Ann. Tour. Res. 2004, 31, 697-711. [CrossRef]

19. Koenig-Lewis, N.; Bischoff, E.E. Seasonality research: The state of the art. J. Tour. Res. 2005, 7, 201-219. [CrossRef]

20. Fernández-Morales, A.; Mayorga-Toledano, M.C. Seasonal concentration of the hotel demand in Costa del Sol: A decomposition by nationalities. Tour. Manag. 2008, 29, 940-949. [CrossRef]

21. Duro, J.A. Seasonality of hotel demand in the main Spanish provinces: Measurements and decomposition exercises. Tour. Manag. 2016, 52, 52-63. [CrossRef]

22. Martín, J.M.; Jiménez, J.; Molina, V. Impacts of seasonality on environmental sustainability in the tourism sector based on destination type: An application to Spain's Andalusia region. Tour. Econ. 2014, 20, 123-142. [CrossRef]

23. Kulendran, N. Modelling Quarterly Tourist Flows to Australia Using Cointegration Analysis. Tour. Econ. 1996, 2, $203-222$. [CrossRef]

24. Kim, J.H. Forecasting Monthly Tourist Departures from Australia. Tour. Econ. 1999, 5, 277-291. [CrossRef]

25. Sørensen, N.K. Modelling the Seasonality of Hotel Nights in Denmark by County and Nationality. Tour. Econ. 1999, 5, 9-23. [CrossRef]

26. Lim, C.; McAleer, M. Monthly seasonal variations: Asian tourism to Australia. Ann. Tour. Res. 2001, 28, 68-82. [CrossRef]

27. Lasanta, T.; Laguna, M.; Vicente-Serrano, S. Do Tourism-Based Ski Resorts Contribute to the Homogeneous Development of the Mediterranean Mountains? A Case Study in the Central Spanish Pyrenees. Tour. Manag. 2007, 28, 1326-1339. [CrossRef]

28. Yacoumis, J. Tackling seasonality: The case of Sri Lanka. Int. J. Tour. Manag. 1980, 1, 84-98. [CrossRef]

29. Lundtorp, S.; Rassing, C.R.; Wanhill, S. The off-Season is 'No Season': The Case of the Danish Island of Bornholm. Tour. Econ. 1999, 5, 49-68. [CrossRef]

30. Jang, S. Mitigating tourism seasonality. A Quantitative Approach. Ann. Tour. Res. 2004, 31, 819-836. [CrossRef]

31. Parrilla, J.C.; Font, A.R.; Nadal, J.R. Accommodation determinants of seasonal patterns. Ann. Tour. Res. 2006, $34,422-436$. [CrossRef]

32. Cuccia, T.; Rizzo, I. Tourism seasonality in cultural destinations: Empirical evidence from Sicily. Tour. Manag. 2011, 32, 589-595. [CrossRef]

33. Lim, C. A Meta-Analytic Review of International Tourism Demand. J. Travel Res. 1999, 37, 273-284. [CrossRef]

34. Duro, J.A.; Farré, F.X. Estacionalidad Turística en las Provincias Españolas: Medición y análisis. Cuad. Tur. 2015, 36, 157-174. [CrossRef]

35. Lopes, H.D.S.; Remoaldo, P.; Ribeiro, V.; Martín-Vide, J. Effects of the COVID-19 Pandemic on Tourist Risk Perceptions-The Case Study of Porto. Sustainability 2021, 13, 6399. [CrossRef]

36. Zhan, L.; Zeng, X.; Morrison, A.M.; Liang, H.; Coca-Stefaniak, J.A. A risk perception scale for travel to a crisis epicentre: Visiting Wuhan after COVID-19. Curr. Issues Tour. 2020, 1-18. [CrossRef] 
37. Smith, W.R. Product differentiation and market segmentation as alternative marketing strategies. J. Mark. 1956, 21, 3-8. [CrossRef]

38. Baum, T.; Hagen, L. Responses to seasonality: The experiences of peripheral destinations. J. Tour. Res. 1999, 1, 299-312. [CrossRef]

39. Sausen, K.; Tomczak, T.; Herrmann, A. Development of a taxonomy of strategic market segmentation: A framework for bridging the implementation gap between normative segmentation and business practice. J. Strat. Mark. 2005, 13, 151-173. [CrossRef]

40. Brännäs, K.; Nordström, J. Tourist Accommodation Effects of Festivals. Tour. Econ. 2006, 12, 291-302. [CrossRef]

41. Sastre, M.A.G.; Hormaeche, M.A.; Villar, M.T. Are Regional Political Decisions the Key Element in Reducing Seasonal Variation in Tourism? The Case of the Balearic Islands. Tour. Econ. 2015, 21, 1207-1219. [CrossRef]

42. Connell, J.; Page, S.J.; Meyer, D. Visitor attractions and events: Responding to seasonality. Tour. Manag. 2015, 46, 283-298. [CrossRef]

43. Wan, C.; Onuike, A. Illuminating Opportunities for Smart Tourism Innovation That Foster Sustainable Tourist Well-Being Using Q Methodology. Sustainability 2021, 13, 7929. [CrossRef]

44. Roman, M.; Roman, M.; Prus, P.; Szczepanek, M. Tourism Competitiveness of Rural Areas: Evidence from a Region in Poland. Agriculture 2020, 10, 569. [CrossRef]

45. Gelbman, A. Tourist Experience and Innovative Hospitality Management in Different Cities. Sustainability 2021, $13,6578$. [CrossRef]

46. Wanhill, S.R.C. Tackling Seasonality: A Technical Note. Int. J. Tour. Manag. 1980, 1, 243-245. [CrossRef]

47. Lau, P.-L.; Koo, T.T.; Dwyer, L. Metrics to measure the geographic characteristics of tourism markets: An integrated approach based on Gini index decomposition. Tour. Manag. 2017, 59, 171-181. [CrossRef]

48. Gini, C.; Variabilità e Mutabilità. Studi Economico-Giuridici Pubblicati per cura della Facoltà di Giurisprudenza della R. Università Di Cagliari; Università degli Studi di Cagliari: Cagliari, Italy, 1912; Chapter 3; pp. 1-158.

49. Markham, C.G. Seasonality of precipitation in the United States. Ann. Assoc. Am. Geogr. 1970, 60, 593-597. [CrossRef]

50. Walsh, R.P.D.; Lawler, D.M. Rainfall seasonality: Description, spatial patterns and change through time. Weather 1981, 36, $201-208$. [CrossRef]

51. Oliver, J.E. Monthly precipitation distribution: A comparative index. Prof. Geogr. 1980, 32, 300-309. [CrossRef]

52. Shannon, C.E. A Mathematical Theory of Communication. Bell Syst. Tech. J. 1948, 27, 379-423. [CrossRef]

53. Barro, R.J.; Sala-i-Martin, X. Convergence. J. Political Econ. 1992, 100, 223-251. [CrossRef] 